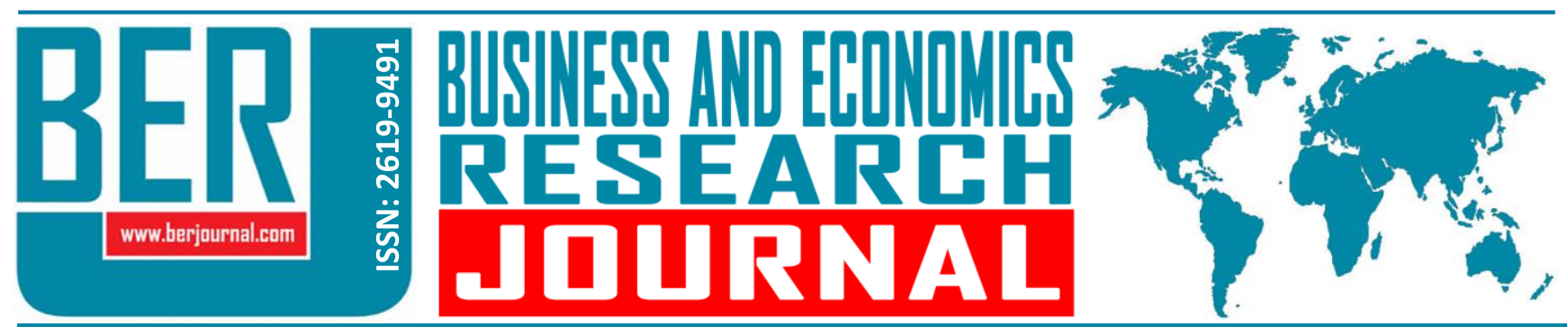

Business and Economics Research Journal Vol. 10, No. 1, 2019, pp. 277-296 doi: 10.20409/berj.2019.168

\section{Reklam İçeriğinin Satın Alma Niyetine Etkisi: Davranışa Yönelik Tutumun Aracı ve Çevresel Endişenin Düzenleyici Rolü*}

\author{
Bilge Nur Ozturk ${ }^{\mathrm{a}}$, Serkan Akinci ${ }^{\mathrm{b}}$
}

Öz: Bu araştırmada, tüketicilerin davranışa yönelik tutumları aracılığıyla, reklam içerikleri ve satın alma niyetleri arasında varsayılan ilişkide çevresel endişenin rolü sorgulanmıştır. Bu amaçla manipüle edilmiş basılı reklam afişleri kullanılarak iki deney gerçekleştirilmiştir. Araştırma sonucunda üç temel bulguya ulaşılmıştır. Ilk olarak, reklam içerikleri ile davranışa yönelik tutum arasındaki ilişkide çevresel endişenin düzenleyici rolüne yönelik destek bulunmuştur. ikinci olarak, tüketicilerin davranışa yönelik tutumlarının, reklam içerikleri ve satın alma niyeti arasındaki ilişkide aracılık rolü olduğu belirlenmiştir. Üçüncü bulgu ise reklam içeriklerinin tüketicilerin davranışa yönelik tutumları aracılığıyla satın alma niyetlerine etkisinin, çevre hakkındaki endişe düzeylerine bağımlı olmasıdır. Araştırma, tüketici davranışı çalışmalarında yaygın bir kullanım oranına sahip olan Planlı Davranış teorisine dayanmaktadır. Bu çerçevede gerçekleştirilen araştırmanın iki önemli katkısı bulunmaktadır. Birincisi, öne sürülen kavramsal model kapsamında, tüketicilerin çevresel endişe düzeylerinin ne zaman yeşil tüketim davranışını etkilediğinin belirlenmiş olmasıdır. ikinci olarak da araştırmanın reklamlar üzerinden deneysel tasarım yöntemi ile gerçekleștirilmesidir.

\section{The Impact of Advertising Content on Purchase Intention: A Moderated Mediation Model of Attitude toward the Product and Environmental Concern}

Abstract: In this research, the effect of advertising content on purchase intention through the consumers' attitudes towards behavior depend on their environmental concern have questioned. For this purpose, two experiments were carried out using manipulated printed advertising banners. Three basic findings have been reached. First, results were support for the moderator role of environmental concern between advertising content and attitude toward behavior. Second, consumers' attitudes toward behavior were determined to have a mediating role between advertising content and intent to purchase. The third finding is that the relationship between ad content and purchase intention, through the consumers' attitude toward behavior were affected by the level of environmental concern. The research is based on the Planned Behavior Theory, which has a widespread use rate in consumer behavior studies. The research carried out in this framework has two important contributions. The first is that, within the conceptual model proposed, it has been determined when the consumer's environmental concern affects green consumption behavior. Secondly, the research is carried out through the experimental design method through advertisements.
Anahtar Sözcükler: Reklam içerikleri, Tutum, Satın Alma Niyeti, Yeşil Tüketim, Çevresel Endişe

JEL: M30, M31, M37

$\begin{array}{ll}\text { Geliş } & : \text { 16 Ekim } 2018 \\ \begin{array}{l}\text { Düzeltme } \\ \text { Kabul }\end{array} & : 28 \text { Kasım } 2018 \\ & : 08 \text { Ocak } 2019 \\ \text { Tür } & : \text { Araştırma }\end{array}$

Keywords: Advertisement Content, Attitude, Purchase Intention, Green

Consumption, Environmental Concern

JEL: M30, M31, M37

Received : 16 October 2018

Revised : 28 November 2018

Accepted : 08 January 2019

Type : Research

a Asst. Prof., PhD., Alanya Alaaddin Keykubat University, Faculty of Management, bilge.ozturk@alanya.edu.tr (ORCID ID: 0000 0001-9232-3912)

b Assoc. Prof., PhD., Akdeniz University, Faculty of Economics and Administrative Sciences, Business Administration Department, sakinci@akdeniz.edu.tr (ORCID ID: 0000-0003-3854-1657) 


\section{Giriş}

Insanların çevre ile ilgili ortaya çıkan küresel ısınma, ozon tabakasının incelmesi, hava kirliliği, toprak erozyonu ve ormanların yok olması gibi sorunların farkına varmaya başlaması onların gelecek nesiller ve dünyanın geleceği hakkında endişelenmelerine yol açmaktadır (Akehurst, Afonso ve Gonçalves, 2012). Bunun sonucu olarak toplumlarda çevreci düşünce sistemleri üzerine kurulan yeşil hareketler ortaya çıkmıştır. Son 20 yıl içerisinde artan çevrecilik akımı tüketicilerin bir kısmının sürdürülebilir tüketimi benimsemesini yansıtmaktadır (Paul, Modi ve Patel, 2016). Yeşil tüketim kavramı 1970'lerde dillendirilmeye başlanmıştır (Peattie, 2010). Kendi tüketimleriyle ilgili çevre problemlerinin farkına varan yeni tüketici bölümü kendileri ve gelecek nesillerin faydasını da göz önüne alarak çevre dostu ürünler tüketme arayışına girmiştir. Pazarlama bilimi sınırları içerisinde gelişmeleri takip eden araştırmacılar tüketicilerin bir kısmındaki tüketim alışkanlıklarındaki bu değişimi fark ederek konu üzerine çalışmalar yapmaya başlamıştır (Straughan ve Roberts, 1999). Günümüzde yeşil tüketici olarak kavramsallaştırılan tüketici pazar bölümü oluşmuş ve çevreye duyarlı üretim ve tüketim süreçlerinin tanımlanmasına katkı sağlamıştır. Hükümetlerin bu konuya ilişkin yasal düzenlemeleri ile birlikte, sürdürülebilirlik düşüncesi üzerine kurulan kamuoyu beklentisi işletmelerin üretim, pazarlama ve iletişim süreçlerini etkilemiştir (Hult, 2011).

Çevreci akımının temelinde yatan çevresel endişe kavramı yeşil pazarlama literatüründeki sürdürülebilirlik değişkenleri arasındaki en önemli faktörlerden birisidir (Paul vd., 2016). Bu alanda yapılan çalışmalar sıklıkla çevresel endişe kavramına değinmektedir (ör. Lin ve Huang, 2012; Zhao, Gao, Wu, Wang ve Zhu, 2014). Dunlap ve Van Liere (1978) tarafından öne sürülen Yeni Çevre Paradigması, materyalist toplumlarda gelinen düşünsel birikimin son uzantısı olarak değerlendirilmektedir. Bu düşünce sistemine göre mutluluk ve kişisel tatmin, materyal değerlere daha az ve sağılı, zaman, huzur, doğa ile bütünleşme gibi diğer soyut kavramlara daha fazla sahip olmaktan geçmektedir (Peattie ve Peattie, 2009).

Bu değerler dizisi çerçevesinde ortaya çıkan yeni tüketici kitlesi, 90'lı yıllardan itibaren tüketici araştırmalarının en gözde konularından biri haline gelmiştir. Çevre duyarlı tüketim ve çevre bilinçli tüketici bağlamında pek çok tanımlayıcı araştırma yapılmaya başlanmıştır. Bu çalışmalarda, yeni tüketici grubunun demografik ve psikografik özellikleri belirlenmeye çalışılmıştır (ör. Shrum, McCarty ve Lowrey, 1995; Roberts, 1996; Diamantopoulos, Schlegelmilch, Sinkovics ve Bohlen, 2003).

Pazarlama açısından tüketicileri çevreye duyarlı tüketime motive eden etmenleri belirleyebilmek giderek önemli bir konu haline gelmiştir. Bu etmenler, tüketicilerin bireysel özellikleri, içinde bulunulan toplumun ortak düşünsel süreçleri, hükümetlerin yasal düzenlemeleri gibi faktörlerden etkilenmektedir. Kotler (2011) bu bağlamda sürdürülebilirliğin sağlanabilmesi için şirketlerin araştırma ve geliştirme, üretim, finans ve pazarlama uygulamalarında ciddi değişiklikler yapmaları gerektiğini önermektedir. Bu gerekliliğin temel nedeni olarak da tüketici baskısına dikkat çekmektedir. Tüketicilerin, markalar arasında temel seçim kriteri olarak ilk başlarda fonksiyonel, daha sonra duygusal ve günümüzde ise bunlara üçüncü bir boyutun eklenerek firmaların sosyal sorumluluklarını nasıl yerine getirdikleri kriterini temel aldıklarını belirtmiştir. Diğer yandan işletmeler de, bu yeni çevre dostu sistemlere dâhil olduklarını göstermek için girişimlerde bulunmaya başlamışlardır. Tüketicilerin çevresel endişelerinin farkına varan işletmelerin çevreci iddialara sahip reklamları kullanmaya başlamaları şaşırtıcı olmamıştır (Shrum vd., 1995). Reklamları kullanarak işletmeler, çevre dostu ürünler ve üretim süreçleri hakkında tüketicilere bilgi akışı sağlayabilmektedir. Bu sayede, toplumsal duyarlılıkları üzerine vurgu yaparak kurumsal imajlarını da geliştirmektedirler.

Bu bağlamda reklam içeriklerinin tüketicilerin satın alma niyetlerine etkisinin belirlenmesi reklamların etkinliği açısından önemli olduğu düşünülmektedir. Bu çalışmada, bu etkinin tüketicilerin çevresel endişe düzeyleri açısından ne zaman ve nasıl gerçekleştiğini belirlemek amaçlanmıştır. Bu amaçla geçmiş çalışmalar ve teorilere dayanılarak geliştirilen bir kavramsal model bir dizi araştırma sorusu çerçevesinde deneysel tasarım yöntemiyle test edilmiştir. Çalışmada basılı reklam içerikleri ile satın alma niyetleri arasındaki ilişki tüketicilerin davranışa yönelik tutumları aracılığıyla açıklanmaya çalışımıştır. Ayrıca bu ilişkide çevresel endişe kavramının düzenleyici rolü deneysel tasarım yöntemi ile test edilmiştir. Konuyla ilgili literatür taraması, araştırma modeli ve hipotezleri araştırmanın bir sonraki kısmında sunulmuştur. 


\section{Literatür}

\subsection{Davranışa Yönelik Tutum ve Davranış Niyeti İlişkisi}

Davranışsal seçimler konusunda yaygın olarak kullanılan popüler sosyo-psikolojik teorilerden biri Planlı Davranış Teorisidir (PDT) (Ajzen, 1985; Ajzen, 1991). Tutumlarla davranışlar arasındaki bağlantıyı açıklayan bir teori olan PDT, Nedenli Eylem Teorisinin (Sheppard, Hartwick, ve Warshaw, 1988; Fishbein ve Ajzen, 2011) geliştirilmiş modelidir (Ajzen ve Madden, 1986). PDT geniş anlamda, sonuçlanmış eylemleri açıklarken kullanılan, sosyal psikoloji çerçevesinde oluşturulmuş ve sebep-sonuç ilişkisine dayanan süreçleri gösteren bir teoridir. Teorinin varsayımına göre davranış, eylemin olası sonuçları (olumlu veya olumsuz) hakkındaki inançlar, algılanan sosyal baskı veya öznel normlar ve eylem üzerindeki algılanan davranışsal kontrol tarafından belirlenmektedir. Bu faktörler ne kadar kuvvetli ise, kişinin davranış niyetinin oluşması ve sonuç olarak da davranış eyleminin gerçekleşmesi ihtimali de o derece yüksektir (Ajzen, 2005: 118). PDT'ye göre davranış, davranışsal niyetin doğrudan fonksiyonudur. Davranışsal niyete üç faktör yön vermektedir. Bu faktörler "davranışa yönelik tutum" (davranışı gerçekleştirmenin pozitif ya da negatif değerlendirmesi), "öznel norm" (davranışı gerçekleştirmeye ya da gerçekleştirmemeye yönelik sosyal baskı) ve "algılanan davranışsal kontrol" (davranışı gerçekleştirmenin zorluğu ya da kolaylığı) olarak belirlenmektedir. Teoriye göre davranışın öncülü ise niyettir (Ajzen, 1991; Tonglet, 2002). Niyetin dolayısıyla davranışın en temel belirleyicisi olan davranışa yönelik tutum, "söz konusu davranışın gerçekleştirilmesi hakkında kişinin genel değerlendirmesi" olarak tanımlanmaktadır (Ajzen, 2002: 5). PDT çalışmalarına göre davranışa yönelik tutum, modelin diğer boyutları olan öznel norm ve algılanan davranışsal kontrol değişkenlerine göre, niyeti daha fazla etkilemektedir (Ajzen, 2008). Krueger, Reilly ve Carsrud (2000) niyetlerin başarılı bir şekilde davranışları tahmin ettiğini, tutumların da başarılı bir şekilde niyetleri tahmin ettiğini ifade etmişlerdir. Tutumlar ne kadar pozitif olursa, davranışa yönelik niyetler de o ölçüde yüksek olacaktır. Diğer konularda olduğu gibi, yeşil satın alma niyetinin en temel etkileyicilerinden birisinin de tutum değişkeni olduğu yönünde bulgular bulunmaktadır (Minton ve Rose, 1997).

Diğer yandan yeşil ürün satın alma niyeti ve davranışı açısından reklamın kendisi önemli bir teşvik edicidir. Tüketiciler yeşil reklamlarla var olan çevresel duyarlılıkları ve endişelerini güçlendirip yeşil satın almaya yönelebilecekleri gibi, bu konuda bilinçlenerek çevresel duyarlııklarını da geliştirebilmektedirler. Eğer kişilerin yeşil davranışa yönelik tutumları ve yeşil satın alma davranışları daha yüksekse, fonksiyonel reklamlar tüketicilerin reklama yönelik tutumları üzerinde daha etkileyici olabilmektedir (Matthes, Wonneberger, ve Schmuck, 2014). Yeşil ürün alma davranışına sahip tüketiciler, genellikle reklamlarda sunulan iddialarla motive olmaktadırlar. Yeşil tüketici profili genellikle reklamdaki duygusal ögelerden ziyade reklamı yapılan davranışa yönelik bilgi edinmeyi önemsemektedir (Shrum vd., 1995). Buradan hareketle PDT'ye ve geçmiş çalışma sonuçlarına dayanarak aşağıdaki hipotez geliştirilmiştir:

Hipotez 1: Yeşil reklam içeriği ile davranışa yönelik tutum arasındaki ilişki çevresel endişe düzeyi yüksek olan bireylerde düşük olanlara göre daha yüksek olacaktır.

\section{2. Çevresel Endişe}

"Çevresel endişe" terimi, politik söylemden türetilmiştir. Çevreye ilişkin değerler, tutumlar, duygular, algılar, bilgi ve davranışları ifade eder (Bamberg, 2003). Temel olarak çevresel endişe, belirli çevresel davranışların doğrudan bir öncülüdür ve davranışlar da bu davranışlara yönelik tüketici tutumları ile tahmin edilmektedir (Ajzen ve Fishbein, 1977). Diğer yandan çevre bilinci çalışmalarında en sık rastlanılan kavram, Yeni Çevre Paradigması (YÇP) kavramıdır. İnsanların çevre ile ilgili genel görüşlerini, bakış açılarını öğrenmek için etkili bir yöntem olarak görülmektedir. 1970'lerde, insanlığın doğanın bir bileşeni olarak değerlendirildiği ve belli başlı limitlerin olduğu düşüncesi ile birlikte YÇP düşüncesinin yükselişi başlamıştır. Bu düşünce, çevresel problemlerin insanlara, çevre ve çevre ile olan ilişkilerini düşünme fırsatı sunacağını, çevre odaklı ve insanı merkeze almayan, doğayı bir bütün olarak değerlendiren bir görüşten bahseder (Dunlap, Van Liere, Mertig ve Jones, 2000). YÇP, insanlığın, doğanın dengesinin bozulması, toplumlar için belli büyüme sınırlarının var olması ve insanların doğanın geri kalanına müdahale etme haklarını içeren konulardaki inançlarına odaklanmaktadır. 
Araştırmacılar, çevresel endişe söz konusu olduğunda, kişisel değişkenlerin, sosyo-ekonomik değişkenlerden daha iyi tahmin ediciler olduklarını tespit etmişlerdir (Kinnear, Taylor ve Ahmed, 1974; Schwepker, Charles ve Cornwell, 1991). Kişisel normların çevre dostu davranışı etkileyen temel bileşenler olduğu yönünde bulgular vardır (Minton ve Rose, 1997). Kişisel değerler, çevresel endişe, çevre koruma davranışları ve tutumlarını açıklarken etkili olmaktadır. Doğaya yakınlık, doğayı koruma isteği arttıkça, çevre koruma davranışı ve çevresel endişe artmaktadır (Granzin ve Olsen, 1991). Dünyayı korumaya dair kişisel değerlerdeki artış, çevre ile ilgili endişeyi de artırmaktadır. Zengin ve müreffeh bir yaşantıya ait değerlerde (materyalist değerler) artış ise çevre ile ilgili endişeyi azaltmaktadır. Başkalarını düşünmeye dair (altruistik) değerlerin artışı, çevresel endişeyi ve çevreye yönelik pozitif tutumları artırmaktadır. Çevresel endişe düzeyi yüksek kişiler, çevre koruma aktivitelerinden zevk almakta ve sade bir yaşantı sürmekten mutluluk duymaktadırlar. Ayrıca dini hassasiyetler arttıkça çevre duyarlılığında ve sürdürülebilir davranışlarda artış görülmektedir (Granzin ve Olsen, 1991; Minton, Kahle ve Kim, 2015). Genellikle, gençlerin çevreye karşı endişelenme tutumları daha fazla olmaktadır (Van Liere ve Dunlap, 1980). Ancak daha yaşlı kişiler de geri dönüşüm aktivitelerine daha fazla katılım göstermektedirler (Vining ve Ebreo, 1990). Eğitim düzeyi arttıkça çevresel endişe ve çevre koruma aktivitelerine katılım artmaktadır (Van Liere ve Dunlap, 1980). Aynı şekilde, enerji tasarrufu ve çevreyi korumak için ekstra ücret ödemeye olan gönüllülük de artmaktadır. Yüksek gelir düzeyi geri dönüşüm aktivitelerine katılımı pozitif yönde etkilemektedir (Vining ve Ebreo, 1990). Yüksek sosyal sınıf, çevresel meselelerle ilgili politik girişimleri pozitif etkilemektedir (Mohai, 1985). Hanedeki çocuk sayısı da çevresel meselelerde etkilidir. Çocuk sayısı arttıkça ekolojik ürünler tüketme eğilimi artmaktadır (Brooker, 1976). Ancak çevreyi temiz tutmak adına ekstra ücret ödemeye gönüllülük değerinde ise azalma görülmektedir (Jackson, 1983). Özetle, mevcut araştırmalarda çevresel endişe düzeyi yüksek olan tüketicilerin demografik özellikleri açısından net olarak bir farklılaşma olmasa da genellikle cinsiyeti kadın, eğitim ve gelir düzeyi yüksek ve beyaz yakalı olma eğiliminde oldukları görülmektedir (Diamantopoulos vd., 2003; Granzin ve Olsen, 1991). Yaş konusunda ise birbirinden farklı sonuçlar bulunmaktadır. Çevreci eğilimleri olan, yaşı genç, eğitim seviyesi yüksek ve politik ideolojileri liberal olan kişiler, YÇP ölçeğinde daha yüksek puan almaktadırlar (Dunlap vd., 2000). YÇP skoru yüksek kişiler, çevre yanlısı tutumlar gösteren kişilerdir. Ek olarak, çevre ile ilgili endişe düzeyi yüksek olan bireylerin, çevreye karşı bilinçli davranmaya daha meyilli olmaları beklenmektedir. Örneğin, yüksek çevresel endişeye sahip tüketicilerin, geri dönüşüm, enerji tüketimi gibi konulara daha fazla yöneldikleri tespit edilmiştir (Roberts ve Bacon, 1997). Literatürdeki bu çalışmalar ışığında aşağıdaki hipotezler geliştirilmiştir.

Hipotez 2: Reklam içeriği ile satın alma niyeti arasındaki ilişkide davranışa yönelik tutumun aracılık rolü vardır.

Hipotez 3: Çevresel endişe düzeyi, davranışa yönelik tutum aracılığıyla reklam içeriği ve satın alma niyeti arasındaki dolaylı ilişkide düzenleyici rol oynayacaktır.

\section{Araştırmanın Kavramsal Modeli}

Araştırmanın kavramsal modeli Şekil 1'de sunulmuştur. Öne sürülen modelde, reklam içeriğinin davranışa yönelik tutum üzerindeki etkisi, çevresel endişe düzeyine bağımlıdır. Bir başka ifadeyle, reklam içeriği ile davranışa yönelik tutum arasındaki ilişkide çevresel endişenin düzenleyiciliği söz konusudur. Modelde reklam içeriği bağımsız değişken $(X)$, davranışa yönelik tutum aracı değişken $(M)$ çevresel endişe $(W)$ düzenleyici değişken ve satın alma niyeti $(Y)$ de bağımlı değişkendir.

Aracı değişkenler, bir etkinin varlı̆ı̆na dair mekanizmaları işaret ederken, düzenleyici değişkenler var olan bu etki hakkında bilgi sağlamaktadırlar (Mackinnon, 2008: 11). Aracı etkinin var olduğu bir modele dayanarak, aynı modelde düzenleyici bir etkinin varlığından da bahsetmek mümkündür. Bu düzenleyici etki mekanizması, "bağımsız değişken ya da tahmin edici değişken ile bağımlı değişkenin arasındaki ilişkinin yönünü ve/veya gücünü etkileyen, nitel (ör. Cinsiyet, sınıf) veya nicel (ör. Ödül düzeyi) değişken" olarak tanımlanmaktadır (Baron ve Kenny, 1986: 1174). Düzenleyici değişkenlerin olduğu bir ilişkide, bağımsız değişken ile bağımlı değişken arasındaki ilişki, düzenleyici değişkendeki değişime göre farklılaşmaktadır (MacKinnon, 2008: 276). Bu bağlamda, varlığı tespit edilmiş bir aracı etki modeline dayanarak düzenleyici etkilerden bahsetmek mümkün olacaktır. 
Şekil 1. Reklam İçeriğinin, Satın Alma Niyetine Davranışa Yönelik Tutum Aracılığıyla Etkisinde, Çevresel Endişenin Düzenleyici Rolünü Öne Sürdüğümüz Kavramsal Model

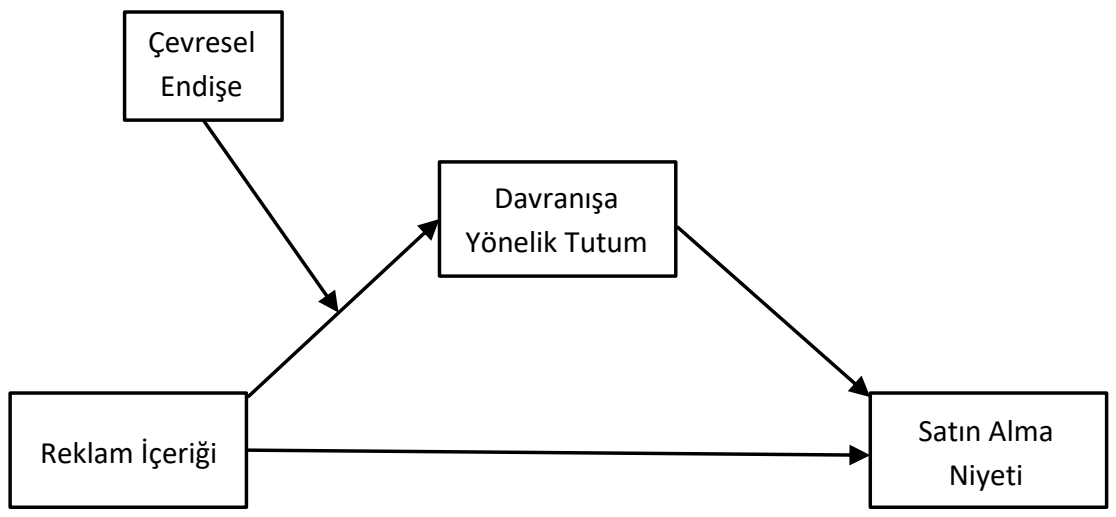

Öne sürdüğümüz model literatürde "düzenlenmiş aracılık" modeli (moderated mediation) olarak adlandırılmakta ve reklam içeriğinin satın alma niyetine etkisinin düzenleyici değişken yardımıyla ne zaman ve aracı değişken yardımıyla da nasıl oluştuğunu açıklamaya yöneliktir (Muller, Judd ve Yzerbyt, 2005; Preacher, Rucker ve Hayes, 2007). Bu modeldeki olası ilişkiler, elde edilen verilerle birlikte koşullu bir süreç modeli kullanılarak SPSS programına eklenen bir makro aracılığıyla test edilmiştir. Koşullu süreç analizi, Andrew F. Hayes tarafından geliştirilen bir makro aracılığıyla düzenleyici etki ile aracı etkiyi birleştiren bir veri analizi yöntemidir (Hayes, 2013). Süreç analizi, en küçük kareler regresyon analizini kullanmakta ve dolaylı etkinin örneklem dağııımını ampirik olarak tahmin ederken, "bootstrapping" olarak adlandırılan yöntemden faydalanmaktadır.

\section{Metodoloji}

\subsection{Araştırma Tasarım}

Araştırma hipotezleri deneysel tasarım yöntemiyle test edilmiştir. Bu amaçla uygulanacak araştırmada dört farklı reklam afişinin kullanılması planlanmıştır. Reklam afişleri, standart ve yeşil iddialar içerecek şekilde iki grupta tasarlanmıştır. Yeşil içerikli reklam afişlerinde yer alacak ifadeler her iki ürün için yeşil-çevre dostu özellikler içermesi, standart içerikli reklam afişlerinde ise aynı ürünler için standart özellikleri içermesi planlanmıştır. Standart afişlerin tasarımında ürün tanıtım ifadelerinde klasik özellikler yer alırken, yeşil içerikli afişlerde ürün tanıtım bilgilerinde çevre duyarlı ifadelere yer verilmiştir. Çevre yönelimli davranış çalışmalarında ve yeşil reklamlarda sık olarak kullanılan "ekolojik, eco, hibrit, geri dönüştürülebilir, doğaya saygılı, doğal kaynakları koruyucu, karbon ayak izi, sürdürülebilir, yeşil" gibi ifadeler yeşil içerikli reklamlarda yer almıştır. Bu ifadelere ek olarak, yeşil içerikli afişlerde, ilgili ürünün ekolojik olduğunu gösteren bir de logo eklenmiştir.

\section{2. Ürün Seçimi}

Tasarlanacak reklamlarda yer alacak ürün kategorisini ve ürünü belirlemek amacıyla iki ön çalışma gerçekleştirilmiştir. Illk çalışmada, araştırma popülasyonu içerisinde yer alan lisans öğrencilerine $(n=154)$ "çevreye karşı duyarlı, doğa dostu, ekolojik ve yeşil bir ürün olmasını isteyeceğiniz ilk 3 ürün nedir?" şeklinde açık uçlu bir soru yöneltilerek elde edilen yanıtlar frekans değerlerine göre sıralanmıştır. Sıralama sonucunda belirlenen ilk 8 ürün kategorisi kullanılarak ikinci bir ön çalışma gerçekleştirilmiştir. Katılımcılardan, $(n=100)$ ürün kategorilerinin çevreye karşı duyarlı, doğa dostu, ekolojik ve yeşil ürün olması açısından önem derecelerini "1=kesinlikle önemsiz ve 7=kesinlikle önemli" olmak üzere yapılandırımış 7 noktalı bir ölçek aracılığıyla belirtmeleri istenmiştir. Katılımcıların yanıtlarından elde edilen puanların ortalamaları incelediğinde otomobil/taşıt kategorisi ilk sırayı $(\bar{X}=5,82)$ alırken, plastik ambalajlı ürünler de ikinci sırayı $(\bar{X}=4,97)$ almıştır. Bu sonuçlar doğrultusunda, araştırmada kullanılacak ürün kategorileri otomobil ve pet şişeli 
su olarak belirlenmiş ve reklam afişlerinde otomobil ve pet şişeli su görsellerinin kullanılmasına karar verilmiştir.

\section{5. Çalışma 1a}

Reklam içeriği, otomobillerde standart ve yeşil özellikleri yansıtması amacıyla manipüle edilerek tasarlanmış reklam afişleridir. Çevresel endişe düzeyi ise, kavramla ilgili ölçek aracılığıyla belirlenmiştir. Katılımcılara tesadüfi olarak atandıkları gruplarda yeşil iddialar içeren bir otomobil reklamı ile standart özellikler içeren bir otomobil reklamı gösterilmiştir. Reklam afişleri arasında minimum farklılaşma sağlamak için standart bir arka fon kullanılmıştır. Her iki reklam afişi de ürün konumu, iddia konumu ve grafikler açısından aynı şekilde tasarlanmıştır (Şekil 2).

Reklam afişlerinde kullanılan otomobil, öğrencilerin var olan bir markaya yönelik algılarını devreye sokup satın alma niyetlerini etkilemesinin önüne geçmek amacıyla Türkiye'de üretimi ve satışı olmayan bir otomobil görseli kullanılarak tasarlanmıştır. Reklam afişlerinde kullanılan otomobil görseli, Tayvan, Çin, Hindistan, Amerika gibi ülkelerde üretilen 6 adet otomobil (Luxgen-Tayvan, Riich-Çin, Reva-Hindistan, HaimaÇin, Baojun-Çin, Amerika-Scion) markası arasından seçilmiştir. Bu 6 adet markaya ait fotoğraflar, otomobil konusunda ilgili ve gelişmeleri takip eden iki akademisyene gösterilmiş, Türkiye tüketicisi içerisinde en az bilinen marka olarak tespit edilen ve Çin'de üretilen spor bir model olan Haima marka bir otomobil tasarımı üzerinden reklam taslağı oluşturulmuştur. Reklamdaki aracın rengi o üründe satışı olmayan bir renkle değiştirilmiş, aracın adı var olmayan bir marka olan "RAXON ZT4" olarak belirlenmiş, "kendi yolunu çiz" şeklinde bir slogan kullanılarak, araç üzerindeki marka görselleri buzlanmıştır. Bu hipotetik marka ve slogan belirlenirken, var olan bir markaya ait isim ve slogan ile aynı olmamasına özen gösterilmiştir. Uygulama aşamasında reklam afişlerindeki otomobili tanıyan öğrenci olmamıştır.

\subsection{Katılımcılar}

Araştırma Akdeniz Üniversitesi, İktisadi ve İdari Bilimler Fakültesi öğrencileri ile 2016 yılında gerçekleştirilmiştir. Veriler her oturumda ortalama 25 kişi olacak biçimde küçük gruplar halinde toplanmıştır. Katılımcılara ilk olarak hipotetik bir otomobile ait reklam afişinin dağııımı yapılmış, ardından anket formu dağııı ımış ve yönlendirme yapılmadan, kısa açıklamalar yapılarak, katılımcıların kendilerine verilen reklamı inceleyerek soruları cevaplamaları istenmiştir. Çalışmaya katılan 350 öğrenciden, ileriki satırlarda detayları anlatılacak olan manipülasyon kontrolünü geçen 264 adet anket sağlanmıştır. Eksik demografik veri belirten 1 anket değerlendirme dışı bırakıldıktan sonra, geriye kalan 263 katılımcının, 140'ının kadın, 123'ünün erkek ve yaş ortalamalarının da 21,79 olduğu belirlenmiştir.

\section{2. Ölçekler}

\subsection{1. Çevresel Endişe}

Katılımcılar endişe düzeylerini 5 ifadeli, 7 noktalı "kesinlikle katılmıyorum" ile "kesinlikle katılıyorum" aralığında yapılandırılmış bir ölçekle puanlamışlardır. Dunlap vd. (2000) tarafından geliştirilmiş olan ölçek; "insanlar doğaya müdahale ettikleri zaman bu genellikle felaketle sonuçlanır", "Insanlar çevreyi oldukça kötü kullanmaktadırlar", "Diğer canlılardan üstün olmamıza rağmen hala doğanın kanunlarına tabiyiz", "Doğanın dengesi çok hassastır ve kolayca bozulabilir", "Böyle giderse, yakında büyük bir çevre felaketi yaşayacağız" biçiminde Türkçeye uyarlanmıştır. Ölçeğin tek boyutluluğunun belirlenmesi amacıyla bir seri keşfedici faktör analizi uygulanmıştır. Analizden önce Kaiser-Meyer-Olkin (KMO) örneklem yeterlilik ölçütüne bakıldığında, KMO değerinin 0,743 ve Barttlet Küresellik testinin de 315,949 ki-kare değeri $(p<0,001)$ anlamlı olduğu görülmüştür. Bu değerler keşfedici faktör analizini gerçekleştirmek için kabul edilebilir sınırların üzerindedir (Hair vd., 2010: 104). Örneklemin analiz için uygunluğu belirlendikten sonra analiz yöntemi olarak temel bileşen analizi ve Varimax rotasyonu kullanılmıştır. Analiz sonucunda değişkenlerin eş kökenlilik (communality) değerleri incelemiş ve "Diğer canlılardan üstün olmamıza rağmen hala doğanın kanunlarına tabiyiz." ifadesine yönelik analiz sonucunun 0,5 değerinin altında olması ve faktör yükünün de $0,7^{\prime}$ den düşük olması nedeniyle silinmesine karar verilmişstir. Geriye kalan dört ifadeye ait faktör yükleri 0,812 - 0,764 
aralığında değerler almıştır. Ortaya çıkan tek faktörlü yapının öz değeri 1'den yüksek, açıklanan varyans oranı \%61,93 ve Cronbach alfa iç tutarlılık değerinin de 0,792 olduğu belirlenmiştir. Güvenilirlik kriteri olarak genel kabul görmüş bir oran olan alfa değerinin 0,70 ve üzeri olması güvenilirliğe bir gösterge olarak referans alınmıştır (Netemeyer, Bearden, ve Sharma, 2003: 58).

\subsubsection{Davranışa Yönelik Tutum}

Katılımcılar davranışa yönelik tutumlarını, Ajzen (2002) tarafından geliştirilen davranışa yönelik tutum için önerilen bir örnekten uyarlanan 4 ifadeli, 7 noktalı çift kutuplu bir ölçekle puanlamışlardır. Ölçek ifadeleri şu şekildedir; "Eğer bu özelliklere sahip bir otomobil satın alırsam... [kötü/iyi bir iş yapmış olurum]", "Benim için bu özelliklere sahip bir otomobil satın almak... [hiç değerli değildir/çok değerlidir]", "Bu özelliklere sahip bir otomobil satın almak beni... [memnun etmez/memnun eder.]" ve "Bu özelliklere sahip bir otomobil satın almak... [ilgimi çekmez/ilgimi çeker]" Dört ifadeden oluşan ölçek, tek boyutluluk ve güvenilirlik açısından test edilmiştir. Analizler sonucunda KMO değerinin 0,841 ve Barttlet Küresellik testinin de 687,628 ki-kare değeri $(p<0,001)$ anlamlı olduğu görülmüştür. Dört ifadeye ait faktör yükleri $0,913-0,828$ aralığında değerler almıştır. Ölçeğin açıklanan varyans oranı \%77,80 ve Cronbach alfa iç tutarlık değeri de 0,904'tür.

\subsubsection{Satın Alma Niyeti}

Öne sürülen modelde bağımlı değişken olarak yer alan satın alma niyeti de 3 ifadeli 7 noktalı çift kutuplu bir ölçekle puanlanmıştır. Ajzen (2002) tarafından geliştirilen örnekten uyarlanan bu ifadeler de şu şekildedir; "Bu özelliklere sahip bir otomobil satın alma ihtimalim... [çok düşüktür/çok yüksektir]", "Gelecekte bu özelliklere sahip bir otomobil satın almak için çaba sarf ederim... [kesinlikle hayır / kesinlikle evet]" ve "Gelecekte bu özellikte bir otomobil satın alma niyetindeyim... [kesinlikle katılmıyorum/kesinlikle katılıyorum]". Analizler sonucunda ölçeğin KMO değerinin 0,604 ve Barttlet Küresellik testinin de 290,729 kikare değeri $(p<0,001)$ anlamlı olduğu görülmüştür. Faktör tek boyutluluğunu korumuş ve üç ifadeye ait faktör yükleri 0,912-0,674 arasında değerler almıştır. Satın alma niyeti faktörünün açıklanan varyans oranı \%69,07 olarak gerçekleşmiştir. Ölçeğin iç tutarlılık değeri de 0,768 olarak bulunmuştur.

Hipotez testlerinde kullanılacak ölçeklerin tek boyutluluğu ve iç tutarlılık düzeylerine yönelik testlerin olumlu sonuçları doğrultusunda bir sonraki aşamaya geçilmiştir.

\subsection{Manipülasyon Kontrolü}

Katılımcıların araştırmada kullanılan yeşil ve standart içerikli ürün afişlerinden yeşil ya da standart otomobil özelliklerini ayırt edebilirlik düzeylerini belirlemek için, hazırlanan anket içerisinde "Sizce bu reklamdaki ürün, çevreye duyarlı bir ürün müdür?” sorusu kullanılmıştır. Bu yöntem manipülasyon kontrolünde araştırmacılar tarafından genellikle tercih edilmektedir (ör. Alniacik ve Yilmaz, 2012; Bhatnagar ve McKay-Nesbitt, 2016).

Araştırma sonucunda 350 katılımcının, 172'si yeşil içerikli afişe ve 178'i de normal içerikli afişe maruz kalmıştır. Yeşil afişe maruz kalan 172 kişinin 149'u ürünün yeşil olduğunu belirtmiştir. Yeşil afişi doğru tanımlama oranı \% 87'dir. Standart afişe maruz kalan 178 kişinin $115^{\prime}$ i gördükleri ürünün standart bir ürün olduğunu belirtmiştir. Standart afişi doğru algılama oranı \%65 olarak bulunmuştur. Standart reklamı doğru algılama oranının düşük olmasının nedeni olarak, araştırma örnekleminde bulunan kadınların otomobil ürününe yönelik düşük ilgisi olabileceği düşünülmüştür. Standart afişe maruz kalan katılımcılar ile yeşil içerikli afişe maruz kalan katılımcıların davranışa yönelik tutum ortalamalarını karşılaştırmak amacıyla bağımsız örneklem $t$ testi gerçekleştirilmiştir. Analiz sonucunda yeşil içerikli reklama maruz kalanlar $($ Ort. $=5,15$, $S S=1,38$ ) ile standart içerikli reklama maruz kalanların (Ort. $=4,50, S S=1,50)$ ortalama puanları arasında anlamlı bir fark bulunmuştur; $t(256)=-3,61, p<0,001$. Sonuçlar doğrultusunda otomobil çalışması için manipülasyonun geçerli bir şekilde yapıldığı tespit edilmiştir. 
Şekil 2. Otomobil Reklam İçeriği Manipülasyon Örneği

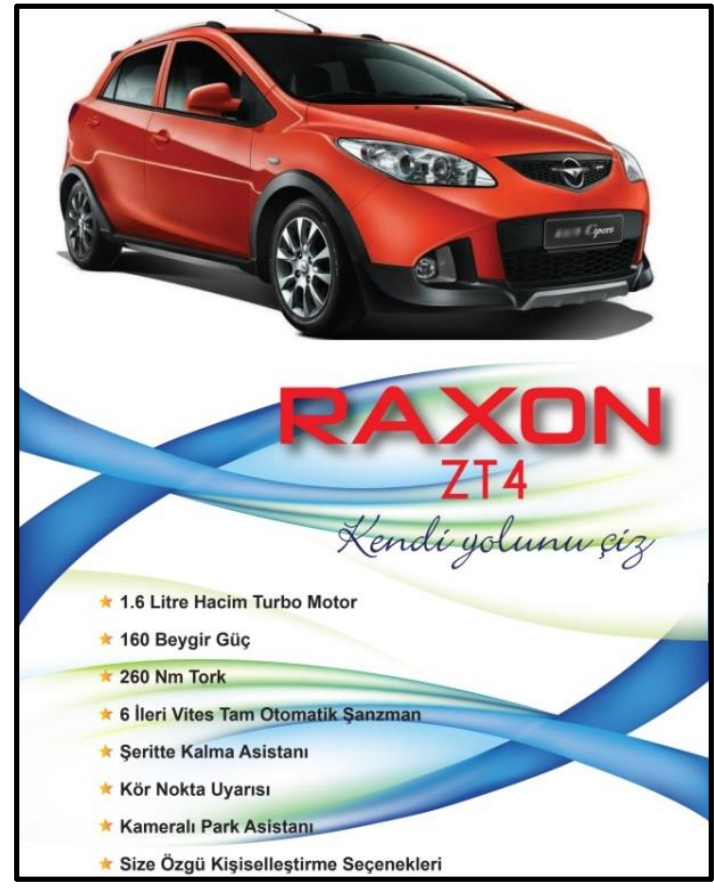

Standart Afiş

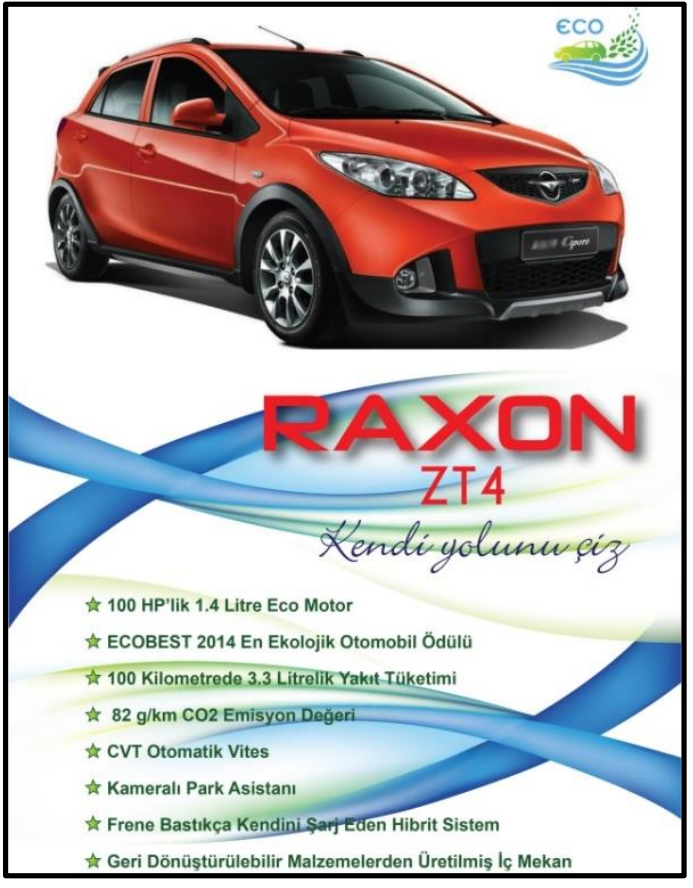

Yeşil Afiş

\subsection{Bulgular}

\section{Reklam içeriği ve davranışa yönelik tutum arasındaki ilişkide çevresel endişenin düzenleyici rolü}

Elde edilen anket verileri incelendiğinde hipotez testlerinin gerçekleştirilebileceği ilgili değişkenlere ait liste bazında tam veriye sahip 258 gözlemin olduğu belirlenmiştir. Eksik veriye sahip gözlemler veri setinden çıkarılmıştır. Veri seti incelendiğinde katılımcıların yaş ortalaması 21,73 ve $\% 53,7$ 'sinin cinsiyetinin de kadın olduğu belirlenmiştir. Öne sürdüğümüz kavramsal modelin (Şekil 1) bir alt modeli olan bu modeli test etmeden önce reklam içeriği $(X)$ ile satın alma niyeti $(Y)$ arasındaki ilişki, normal reklam içeriği gösterilen katılımcılar $(n=110)$ ile yeşil reklam gösterilen katılımcıların $(n=148)$ satın alma niyeti ortalama puanları arasındaki farkın testi değerlendirilerek gerçekleştirilmiştir. Ortalama değerleri sırasıyla 4,12 ve 4,76 olarak bulunmuş ve gruplar arasında anlamlı bir ortalama farkının varlığına yönelik destek bulunmuştur $t(256)=-$ $3,129, p<0,003$. Buna ek olarak reklam içeriği ile satın alma niyeti arasındaki ilişkiyi belirlemek amacıyla pointbiserial korelasyon analizi gerçekleştirilmiştir. Satın alma niyeti ile reklam içeriği arasında pozitif ve anlamlı bir ilişki bulunmuştur $\left(r_{\mathrm{pb}}=0,192, n=258, p<0,003\right)$. Bu sonuçlar doğrultusunda reklam içeriği ile davranışa yönelik tutum arasındaki ilişkide çevresel endişenin düzenleyici rolünü değerlendirmek için IBM SPSS için geliştirilmiş PROCESS 3.0 (Hayes, 2018) makrosu aracılığı ile regresyon temelli basit düzenleyici analizi gerçekleştirilmiştir. Şekil 3'te bu alt modelin yol diyagramı sunulmuştur. Bu modelde, reklam özellikleri ile davranışa yönelik tutum arasındaki ilişkide çevresel endişe düzeyinin düzenleyici rolü test edilmiştir (Hipotez 1).

Çoklu ifadeli bir ölçekle ölçülen çevresel endişe faktörünün daha önce belirlenen tek boyutluluk ve güvenilirlik analizleri sonucuna dayanılarak ifadeleri toplatılarak yeni bir değişken oluşturulmuştur. Bir sonraki aşamada model testini gerçekleştirmek amacıyla oluşturulan bu yeni değişkenin reklam içeriğinin davranışa yönelik tutumu etkileyip etkilemediğini ve etkiliyorsa bu etkinin ne zaman gerçekleştiğini test etmek amacıyla PROCESS 3.0 makrosuyla birlikte Johnson-Neyman tekniği kullanılmıştır. Olası düzenleyici etkisinin grafik olarak gösteriminde geleneksel yöntemler yerine bu tekniğin tercih edilmesinin nedeni düzenleyici değerini net olarak göstermesidir. Düzenleyici değeri geleneksel yöntemlerde rastgele, yüzdelik ya da +/- 1 standart sapma olarak belirlenmektedir. Eğer düzenleyici değişken sürekli değişken özelliği gösteriyorsa bu yöntemde çok daha isabetli bir şekilde gösterime olanak vermektedir (Hayes, 2018: 254). 
Temelde bu analiz, reklam içeriğinin koşullu etkisi için anlamlılık bölgelerini matematiksel olarak türetir, bu da reklam içeriği ve davranışa yönelik tutum arasındaki ilişkinin sıfırdan farklı olduğu düzenleyici aralığındaki değerleri ifade eder (Pollack, Vanepps ve Hayes, 2012).

Şekil 3. Reklam İçeriği ile Davranışa Yönelik Tutum Arasındaki Illişkide Çevresel Endişenin Düzenleyici Rolünü Gösteren Birinci Alt Model

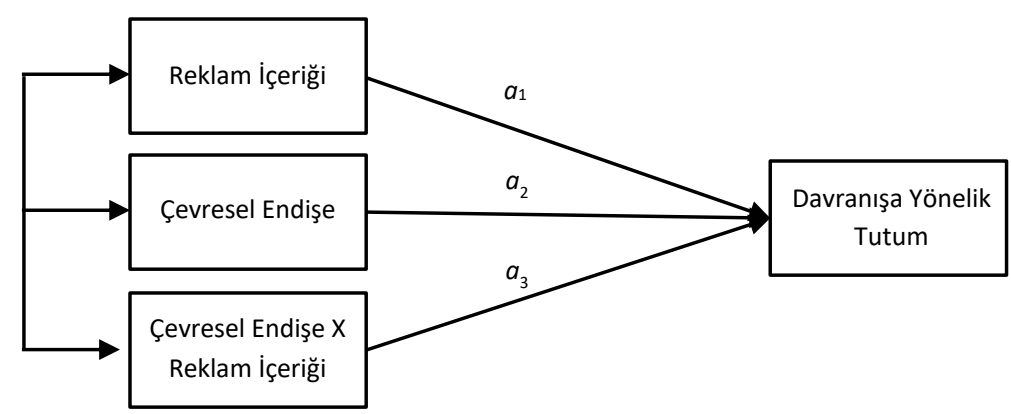

Modelin geneli anlamlıdır, $R^{2}=0,066, F(3,254)=5,97, p<0,001$. Modeldeki bağımsız değişkenler arasındaki çoklu doğrusal bağlantı sorunu, reklam içeriği için VIF=1,00, çevresel endişe için VIF $=1,74$ ve etkileşim değişkeni olan reklam içeriği x çevresel endişe için VIF=1,73 olmasından dolayı bulunmamaktadır. Durbin-Watson $\mathrm{d}=2,05$ değeri kritik değerler olan $1,5<\mathrm{d}<2,5$ değerleri arasında olduğu için çoklu regresyon verisinde birinci derece oto korelasyonun bulunmadığını varsayabiliriz. Analizde olası değişen varyans (heteroskedasticity) sorunun önlemek için HC3 standart hata tahmincisi kullanılmıştır (Long ve Ervin, 2000). Modele etkileşim değişkeni olan (reklam içerikleri) x (çevresel endişenin) dahil edilmesi modelin davranışa yönelik tutum değişkenindeki varyansı açıklama gücünde anlamlı bir artışa neden olmuştur. $\Delta R^{2}=0,02$, $F(3,254)=5,971, p<0,01$.

Şekil 4'te görüldüğü üzere uygulama sonucunda reklam içeriği, davranışa yönelik tutumu çevresel endişenin belirli bir noktasından sonra anlamlı bir şekilde etkilemeye başlamaktadır. Katılımcıların çevresel endişe düzeyleri 5,31'den büyük olduğu durumda reklam içeriğinin davranışa yönelik tutumu etkilemeye başladığı görülmektedir. Bir başka ifadeyle çevresel endişe düzenleyicisinin bir fonksiyonu olarak reklam içeriği ile davranışa yönelik tutum arasındaki ilişkinin sistematik olarak değişkenliği görülmektedir. Çevresel endişenin 5,31 değerinden düşük olduğu durumlarda reklam içeriği davranışa yönelik tutumu etkilememektedir. Bu sonuç birinci hipotezimizi desteklemektedir. Yeşil reklam afişine maruz kalan katılımcıların çevresel endişe düzeyi arttıkça davranışa yönelik olumlu tutumları da artmaktadır. Ayrıca bu sonuç bir sonraki aşamada düzenleyici değişken olarak kullanılacak çevresel endişe ölçeğinin hangi değerde düşük ve yüksek olarak iki kategoriye ayrılması gerektiğini de göstermektedir.

Öne sürdüğümüz kavramsal modelin (Şekil 1) bir diğer alt modeli olan davranışa yönelik tutumun reklam içeriği ile satın alma niyeti arasındaki aracı rolünü test etmek amacıyla basit aracılık analizi uygulanmıştır (Hipotez 2). Araştırma modelinde (Şekil 5), reklam içeriği $(X)$ bağımsız değişken olarak kullanılmıştır. Veri setinde normal reklama maruz kalan katılımcılar "0" olarak kodlanırken yeşil reklama maruz kalan katılımcılar "1" olarak kodlanmıştır. Katılımcıların davranışa yönelik tutum ölçümleri $(M)$ aracı değişken olarak modele dahil olurken, bağımlı değişken olarak da satın alma niyeti $(Y)$ modelde yer almıştır.

Regresyon analizinin sonuçları Tablo 2'de özetlenmiştir. Sonuçlar davranışa yönelik tutumun reklam içeriği ve satın alma niyeti arasındaki ilişkideki aracı rolünü doğrulamıştır. Reklam içeriğinin davranışa yönelik tutum üzerinde pozitif ve anlamlı bir etkisi bulunmaktadır $(a=0,650, p<0,001, \mathrm{Cl}=0,290 \rightarrow 1,010)$. Yeşil içerikli reklam afişine maruz kalan katılımcıların $(X=1)$ normal reklam afişine maruz kalanlara göre $(X=0)$ davranışa yönelik tutumları 0,650 birim daha yüksektir. Davranışa yönelik tutumun satın alma niyetine etkisi, reklam içeriği kontrol edildiğinde istatistiki olarak anlamlıdır $(b=0,755, p<0,001, \mathrm{Cl}=0,677 \rightarrow 0,834)$. 
Şekil 4. Otomobil Reklam İçeriğinin, Çevresel Endişe Değerlerinde Koşullu Etkisi İçin Johnson-Neyman Anlamlılık Bölgeleri

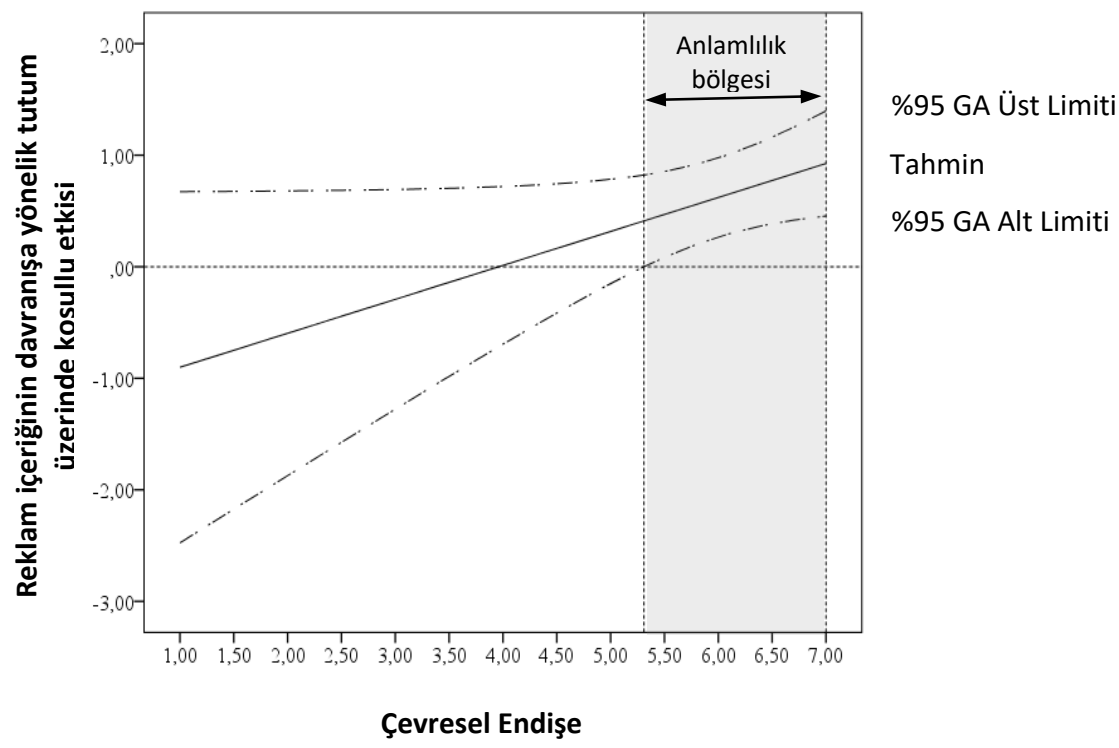

Şekil 5. Reklam İçeriği ile Satın Alma Niyeti Arasındaki ilişkide Davranışa Yönelik Tutumun Aracı Rolü

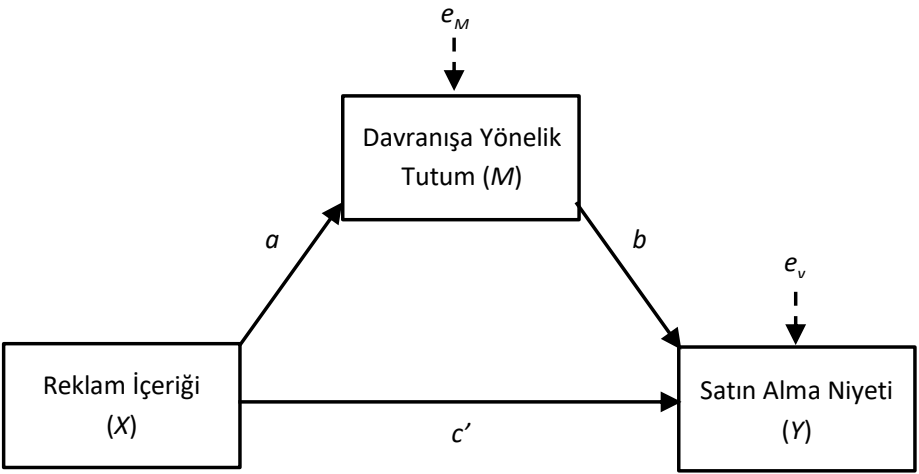

Davranışa yönelik tutumu daha yüksek olan katılımcıların satın alma niyetleri de daha fazladır. Bir başka ifadeyle aynı reklam içeriğine maruz kalmış katılımcılardan davranışa yönelik tutumu bir birim daha fazla olanların satın alma niyetleri 0,755 birim daha fazladır.

Tablo 2. Basit Aracı Modelinin Analiz Sonuçları

\begin{tabular}{|c|c|c|c|c|c|c|c|c|}
\hline \multirow[b]{3}{*}{ Öncüller } & \multicolumn{8}{|c|}{ Ardıl } \\
\hline & \multicolumn{4}{|c|}{ M (Tutum) } & \multicolumn{4}{|c|}{ Y (Satın Alma Niyeti) } \\
\hline & & Katsayı & $\mathrm{SH}$ & $p$ & & Katsayı & $\mathrm{SH}$ & $\underline{p}$ \\
\hline Reklam İçeriği $(X)$ & $a_{1}$ & 0,650 & 0,183 & $<0,001$ & $c^{\prime}$ & 0,079 & 0,122 & 0,517 \\
\hline $\begin{array}{l}\text { Davranışa yönelik tutum } \\
\text { (M) }\end{array}$ & & - & - & - & $b$ & 0,755 & 0,040 & $<0,001$ \\
\hline Sabit & $i_{1}$ & 4,495 & 0,143 & $<0,001$ & $i_{2}$ & 0,517 & 0,178 & $<0,005$ \\
\hline \multicolumn{5}{|c|}{$R^{2}=, 049$} & \multicolumn{3}{|c|}{$R^{2}=0,598$} & \\
\hline & \multicolumn{3}{|c|}{$F(1,256)=12,624, p<0,001$} & & \multicolumn{3}{|c|}{$F(2,255)=201,422, p<0,001$} & \\
\hline
\end{tabular}


Reklam içeriğinin davranışa yönelik tutum aracılığıyla satın alma niyetine dolaylı etkisi istatistiki olarak anlamlıdır $(a b=0,491, \mathrm{Cl}=0,216 \rightarrow 0,776)$. Dolaylı etkinin güven aralığı 10.000 bootstrap ve düzeltilmiş hata tekniği kullanılarak elde edilen örneklemlerden elde edilmiştir. Dolaylı etkiyi gösteren katsayı güven aralığının sıfır içermemesi nedeniyle anlamlıdır (Preacher vd., 2007). Yeşil içerikli reklam afişine maruz kalan katılımcıların davranışa yönelik tutumları aracılığıyla oluşan satın alma niyetleri diğer gruba göre 0,491 birim daha yüksektir. Diğer yandan reklam içeriğinin, satın alma niyetine doğrudan etkisi incelendiğinde istatistiki olarak anlamlı bir sonuç göstermediği anlaşılmıştır $\left(c^{\prime}=0,079, p=0,517, \mathrm{Cl}=-0,161 \rightarrow 0,319\right)$. Bir başka ifadeyle katılımcıların maruz kaldıkları reklam içeriğine göre davranışa yönelik tutumları eşitken satın alma niyetlerine anlamlı bir etki olmamaktadır. Reklam içeriğinin satın alma niyetine toplam etkisi istatistiki olarak anlamlı çıkmıştır $(8=0,570, p<0,003, \mathrm{Cl}=0,217 \rightarrow 0,922)$. Toplam etkinin anlamlı olması ve doğrudan etkinin anlamsız çıkması reklam içeriği ve satın alma niyeti arasında davranışa yönelik tutumun tam aracı rolünü göstermektedir (Baron ve Kenny, 1986).

Çevresel endişe düzeyinin, davranışa yönelik tutum aracılığıyla reklam içerikleri ile satın alma niyeti arasındaki dolaylı ilişkideki düzenleyici rolü

Reklam içeriğinin, davranışa yönelik tutuma etkisine ve davranışa yönelik tutum aracılı̆ıyla reklam içeriğinin satın alma niyetine dolaylı etkisine destek bulunması üzerine bu değişkenler arası dolaylı ilişkide çevresel endişenin düzenleyici rolü test edilmiştir (Hipotez 3). Hipotez 3, reklam içeriğinin satın alma niyeti üzerine etkisinin bir kısmının dolaylı olarak davranışa yönelik tutum aracılığıyla taşındığını ve bu sürecin çevresel endişe tarafından düzenlendiğini öne sürmektedir. Yol analizinde, bir dolaylı etki, öne sürülen neden sabit tutularak bağımsız değişkenin (burada reklam içeriği) aracı değişken üzerine etkisinin ve aracı değişkenin (burada davranışa yönelik tutum) çıktı ya da bağımlı değişkenin (burada satın alma niyeti) üzerine etkisinin çarpımıdır. Eğer bu yollardan bir tanesinde düzenleyici etki bulunuyorsa bu durumda dolaylı etkide de düzenleyici etki vardır (Pollack vd., 2012). Illk analizde (Şekil 3) reklam içeriği ile davranışa yönelik tutum arasındaki yolda düzenleyici etki görülmüştü ve bu yol çevresel endişe tarafından düzenlenmekteydi. edilmiştir.

Şekil 1'de sunulmuş olan kavramsal model Şekil 6'da gösterimi sunulan yol analizi ile tahmin

Tablo 3. Kavramsal Modelinin Analiz Sonuçları

\begin{tabular}{|c|c|c|c|c|c|c|c|c|}
\hline \multirow[b]{3}{*}{ Öncüller } & \multicolumn{8}{|c|}{ Ardıl } \\
\hline & \multicolumn{4}{|c|}{ M (Tutum) } & \multicolumn{4}{|c|}{ Y (Satın Alma Niyeti) } \\
\hline & & Katsayı & $S H$ & $\bar{p}$ & & Katsayı & $S H$ & $p$ \\
\hline Reklam İçeriği $(X)$ & $a_{1}$ & $-0,100$ & 0,384 & 0,795 & $c^{\prime}$ & 0,079 & 0,118 & 0,505 \\
\hline $\begin{array}{r}\text { Davranışa yönelik Tutum } \\
\text { (M) }\end{array}$ & & - & - & - & $b$ & 0,755 & 0,040 & $<0,001$ \\
\hline Çevresel Endişe $(W)$ & $a_{2}$ & $-0,399$ & 0,315 & 0,207 & & - & - & \\
\hline$(W) \times(X)$ & $a_{3}$ & 0,952 & 0,434 & 0,029 & & - & - & \\
\hline Sabit & $i_{1}$ & 4,796 & 0,274 & $<0,001$ & $i_{2}$ & 0,517 & 0,200 & 0,010 \\
\hline & & $R^{2}=, 067$ & & & & $R^{2}=, 598$ & & \\
\hline & & $54)=6,069$ & 0,001 & & & $55)=189,6$ & $p<0,001$ & \\
\hline
\end{tabular}

Reklam içeriğinin satın alma niyeti üzerindeki koşullu dolaylı etkisi $\left(a_{1}+a_{3} \times\right.$ çevresel endişe $) b$, burada Tablo 3'te özetlenen regresyon sonuçlarından davranışa yönelik tutumun satın alma niyeti üzerine kısmi etkisidir. Reklam içeriği ve çevresel endişe düzeyi sabit tutulduğunda davranışa yönelik tutumlarını daha yüksek olarak puanlayan katııımcılar aynı zamanda satın alma niyetlerini de yüksek puanlamışlardır $(b=0,755$, $p<0,001)$.

Reklam içeriğinin davranışa yönelik tutuma olan koşullu etkisi ile davranışa yönelik tutumun satın alma niyetine olan etkisini birleştirdiğimizde, reklam içeriğinin davranışa yönelik tutum aracılığıyla satın alma niyeti üzerine olan endirekt etkisinin de koşullu olduğu görülmektedir. 
Dolaylı etkinin düzenleyici değişken olan çevresel endişe düzeylerindeki büyüklükleri Tablo 4'te sunulmuştur. Görüldüğü üzere düşük endişe düzeyinde bu etkinin anlamlı olmadığı $(\beta=-0,075, \mathrm{Cl}=-0,682 \rightarrow$ $0,538)$ ancak yüksek endişe düzeyinde ise anlamlı olduğu $(B=0,644, \mathrm{Cl}=0,339 \rightarrow 0,966)$ anlaşılmaktadır.

Şekil 6. Çevresel Endişe Düzeyinin, Davranışa Yönelik Tutum Aracılığıyla Reklam Özellikleri İle Satın Alma Niyeti Arasındaki Dolaylı ilişkideki Düzenleyici Rolünü Gösteren Yol Diyagramı

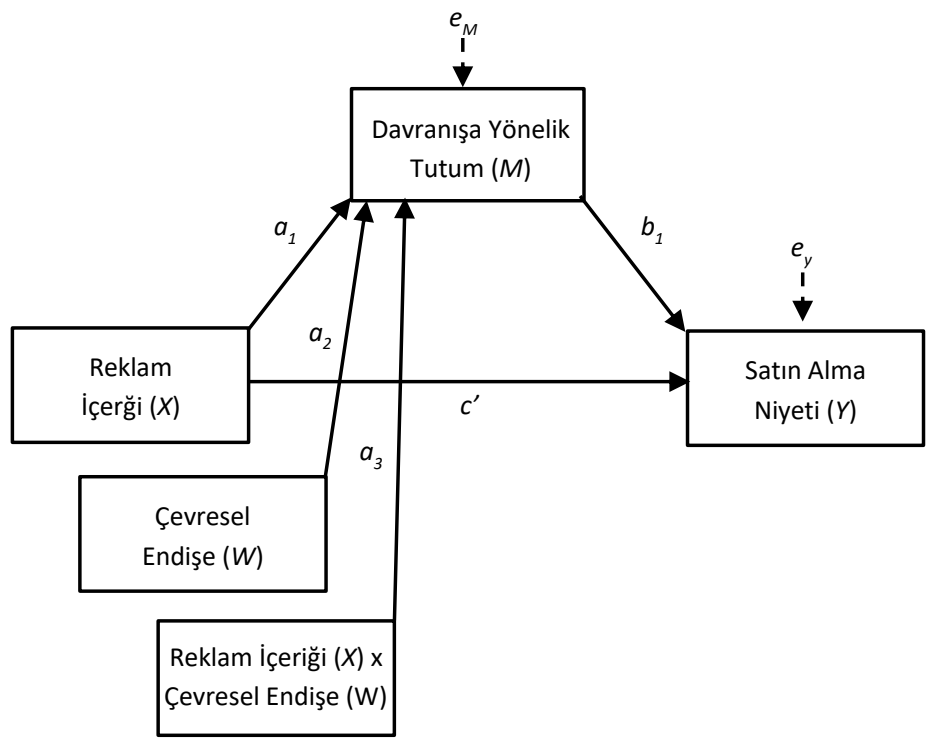

Tablo 4. Çevresel Endişe Değerlerinde, Reklam İ̧̧eriğinin Satın Alma Niyetine Davranışa Yönelik Tutum Aracılığıyla Koşullu Dolaylı Etki Büyüklükleri

\begin{tabular}{llllrrr}
\hline Aracı & \multicolumn{2}{l}{ Çevresel Endişe } & Etki & Boot SE & Boot LLCI & Boot ULCI \\
\hline \multirow{2}{*}{ Davranışa yönelik Tutum } & Düşük & $(0)$ & $-0,075$ & 0,310 & $-0,682$ & 0,538 \\
& Yüksek & $(1)$ & 0,644 & 0,159 & 0,339 & 0,966 \\
\hline
\end{tabular}

Not: $\mathrm{Cl}=\% 95$ dolaylı etki için güven aralığı. Boot=Bootstrap, SE=Standart hata, LLCl=Güven aralığı alt sınıı, $\mathrm{ULCl=Güven} \mathrm{aralığı} \mathrm{üst} \mathrm{sınırı.}$

\section{6. Çalışma 1b}

Araştırma sonuçlarının güvenilirliğini artırmak amacıyla çalışma 1a ile aynı tasarımda benzer bir çalışma daha gerçekleştirilmiştir. Bu çalışmada reklam afişlerinde ürün farklılaştırmasına gidilerek daha önce gerçekleştirilmiş ürün belirleme çalışmasında ikinci sırada yer almış olan pet şişeli hipotetik bir ürün kullanılmıştır (Şekil 7). Katılımcılara yeşil iddialar ve logo içeren bir su reklamı ile standart özellikler içeren klasik bir su reklamı gösterilmiştir. Reklam afişleri arasında minimum farklılaşma sağlamak için standart bir arka fon kullanılmış ve her iki reklam türü de ürün konumu, iddia konumu ve görseller açısından aynı şekilde tasarlanmıştır. Reklamlarda kullanılan su şişesi görünümü, Türkiye'de yaygın olan 9 adet marka arasından, pet şişe tasarımı en standart ve klasik olan ürün şişesi temel alınarak tasarlanmıştır. Pet su şişesi tasarımları, otomobil tasarımı kadar markaya özel detaylandırmalar içermediğinden, Türkiye'deki standart bir su şişesi ile diğer ülkelerdeki pet su şişeleri tasarımları arasında belirgin farklılıklar görülmemektedir. Bu nedenle, bu 9 marka arasından bir seçim yapılması uygun görülmüştür. Ürünün hipotetikleştirilmesi için marka etiketi arka fonu, marka ismi, marka sloganı dahil tüm betimleyiciler değiştirilmiştir. Bu bağlamda yine Türkiye'de satışı olmayan bir marka ve var olmayan bir slogan bulmak için ön araştırmalar yapılmıştır. Su kategorisinin yerel ürünleri de kapsaması nedeniyle pek çok marka, birbirine benzer görseller ve ifadeler içerdiği için marka ve slogan adı özenle belirlenmiştir. Reklamda kullanılan su adı var olmayan bir marka olan "MAVisU" olarak tasarlanmış ve "doğallığın kaynağı" şeklinde bir slogan belirlenmiştir. 


\subsection{Katılımcılar}

Araştırma ilk deneydeki katılımcılardan farklı katılımcılarla yine Akdeniz Üniversitesi, ỉktisadi ve İdari Bilimler Fakültesi öğrencileri ile 2016 yılında gerçekleştirilmiştir. Veriler ilk deneydeki gibi küçük gruplar halinde toplanmıştır. Katılımcılara ilk olarak hipotetik pet şişeli suya ait bir reklam afişinin dağıtımı yapılmış, ardından ilk uygulamada kullanılan anket formuna benzer bir form dağıtılmış ve yönlendirme yapılmadan, kısa açıklamalar yapılarak, katılımcıların kendilerine verilen reklamı inceleyerek soruları cevaplamaları istenmiştir. Çalışmaya 260 öğrenci katılmış, bunların 130' una yeşil içerikli, 130'una ise standart içerikli reklam gösterilmiştir.

\section{2. Ölçekler}

\subsection{1. Çevresel Endişe}

Katılımcıların çevresel endişe düzeylerini belirlemek için bir önceki çalışmada kullanılan ölçeğin aynısı kullanılmıştır. Ölçeğin tek boyutluluğunun belirlenmesi amacıyla bir seri keşfedici faktör analizi uygulanmıştır. Analizden önce Kaiser-Meyer-Olkin (KMO) örneklem yeterlilik ölçütüne bakıldığında, KMO değerinin 0,704 ve Barttlet Küresellik testinin de 241,898 ki-kare değeri $(p<0,001)$ anlamlı olduğu görülmüştür. Temel bileşen yöntemi ve Varimax rotasyonu kullanılan analiz sonucunda değişkenlerin eş kökenlilik değerleri incelemiş ve "Diğer canlılardan üstün olmamıza rağmen hala doğanın kanunlarına tabiyiz." ifadesine yönelik analiz sonucunun 0,5 değerinin altında olması ve faktör yükünün de $0,7^{\prime}$ den düşük olması nedeniyle silinmesine karar verilmiştir. Bu ifade bir önceki deneyde de aynı nedenle silinmiştir. Geriye kalan dört ifadeye ait faktör yükleri 0,843 - 0,753 aralığında değerler almıştır. Ortaya çıkan tek faktörlü yapının öz değeri 1'den yüksek, açıklanan varyans oranı \%60,74 ve Cronbach alfa iç tutarlılık değerinin de 0,774 olduğu belirlenmiştir.

\subsubsection{Davranışa Yönelik Tutum}

Katılımcılar davranışa yönelik tutumlarını, Ajzen (2002) tarafından geliştirilen davranışa yönelik tutum için önerilen bir örnekten uyarlanan 4 ifadeli, 7 noktalı çift kutuplu bir ölçekle puanlamışlardır. Bir önceki deneyde de kullanılan bu ölçek ifade içeriklerinde sadece ürün değişmiştir. Ölçek ifadeleri şu şekildedir; "Eğer bu özelliklere sahip bir su satın alırsam... [kötü/iyi bir iş yapmış olurum]", "Benim için bu özelliklere sahip bir su satın almak... [hiç değerli değildir/çok değerlidir]", "Bu özelliklere sahip bir su satın almak beni... [memnun etmez/memnun eder]" ve "Bu özelliklere sahip bir su satın almak... [ilgimi çekmez/ilgimi çeker]". Ölçek, tek boyutluluk ve güvenilirlik açısından test edilmiştir. Ölçeğin analizi sonucunda $\mathrm{KMO}$ değerinin 0,843 ve Barttlet Küresellik testinin de 516,913 ki-kare değeri $(p<0,001)$ anlamlı olduğu görülmüştür. Dört ifadeye ait faktör yükleri $0,918-0,832$ aralığında değerler almıştır. Ölçeğin açıklanan varyans oranı \%77,91 ve Cronbach alfa iç tutarlık değeri de 0,903 'tür.

\subsubsection{Satın Alma Niyeti}

Öne sürülen modelde bağımlı değişken olarak yer alan satın alma niyeti de 3 ifadeli bir 7 noktalı çift kutuplu bir ölçekle puanlanmıştır. Bu ifadeler de şu şekildedir; "Bu özelliklere sahip bir su satın alma ihtimalim... [çok düşüktür/çok yüksektir]", "Gelecekte bu özelliklere sahip bir su satın almak için çaba sarf ederim... [kesinlikle hayır/kesinlikle evet]" ve "Gelecekte bu özellikte bir su satın alma niyetindeyim... [kesinlikle katılmıyorum/kesinlikle katılıyorum]". Analizler sonucunda ölçeğin KMO değerinin 0,683 ve Barttlet Küresellik testinin de 230,785 ki-kare değeri $(p<0,001)$ anlamlı olduğu görülmüştür. Faktör tek boyutluluğunu korumuş ve üç ifadeye ait faktör yükleri 0,901-0,799 arasında değerler almıştır. Satın alma niyeti faktörünün açıklanan varyans oranı \%73,82 olarak gerçekleşmiştir. Ölçeğin iç tutarlılık değeri de 0,917 olarak bulunmuştur.

Hipotez testlerinde kullanılacak ölçeklerin tek boyutluluğu ve iç tutarlılık düzeylerine yönelik testlerin olumlu sonuçları doğrultusunda bir sonraki aşamaya geçilmiştir. 


\subsection{Manipülasyon Kontrolü}

Pet şişeli su çalışmasına katılan 260 katılımcıdan 130'u yeşil, 130'u standart reklama maruz kalmıştır. 130 yeşil reklamdan 110 'u katılımcılar tarafından yeşil olarak algılanmış (\%85), 130 standart reklamdan 128'i (\%98) standart olarak ifade edilmiştir. Her iki reklam içeriği de katılımcılar tarafından yüksek oranda doğru olarak algılanmıştır. Standart afişe maruz kalan katılımcılar ile yeşil içerikli afişe maruz kalanların davranışa yönelik tutum ortalamalarını karşılaştırmak amacıyla bağımsız örneklem t testi gerçekleştirilmiştir. Analiz sonucunda yeşil içerikli reklama maruz kalanlar $(O r t .=5,95 S S=1,12)$ ile standart içerikli reklama maruz kalanların (Ort. $=4,76, S S=1,58)$ ortalama puanları arasında anlamlı bir fark bulunmuştur; $t(197)=-6,190$ $p<0,001$. Sonuçlar doğrultusunda pet şişeli su çalışması için manipülasyonun geçerli bir şekilde yapıldığı tespit edilmiştir.

Şekil 7. Pet Şişeli Reklam İçeriği Manipülasyon Örneği

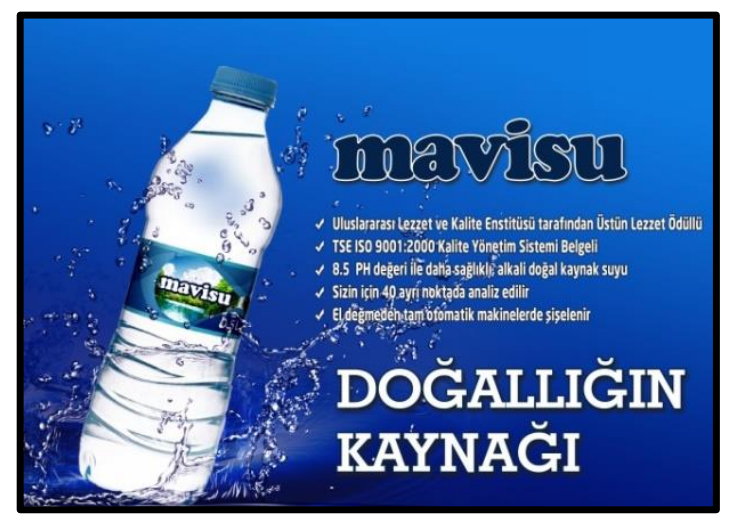

Standart Afiş

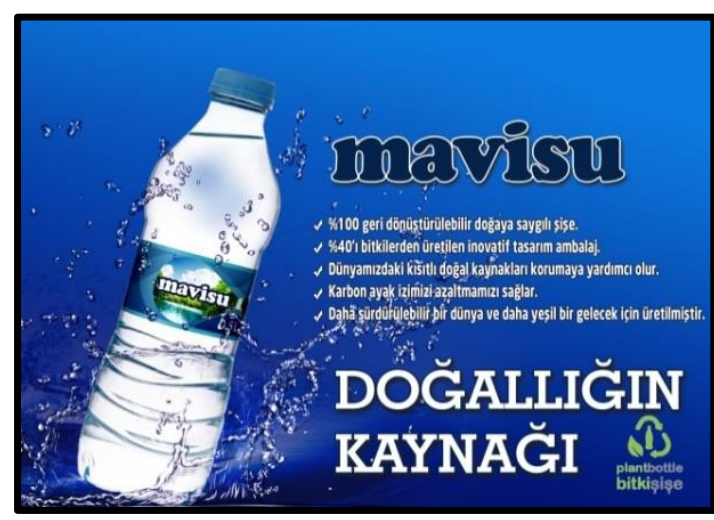

Yeşil Afiş

\subsection{Bulgular}

Elde edilen veriler incelendiğinde hipotez testlerinin gerçekleştirilebileceği ilgili değişkenlere ait tam veriye sahip 199 gözlemin olduğu belirlenmiştir. Eksik veriye sahip gözlemler veri setinden çıkarılmıştır. Veri seti incelendiğinde katılımcıların yaş ortalaması 20,87 ve \%52,3'ünün cinsiyetinin de kadın olduğu belirlenmiştir. Pet şişeli su örneğinde, standart reklam içeriği gösterilen katılımcılar $(n=94)$ ile yeşil içerikli reklam gösterilen katılımcıların ( $n=105$ ) satın alma niyeti ortalama puanları sırasıyla 4,69 ve 5,77 olarak bulunmuş ve gruplar arasında anlamlı bir ortalama farkının varlığına yönelik destek bulunmuştur $t(167)=-$ $5,779, p<0,001$. Buna ek olarak reklam içeriği ile satın alma niyeti arasındaki ilişkiyi belirlemek amacıyla pointbiserial korelasyon analizi gerçekleştirilmiştir. Satın alma niyeti ile reklam içeriği arasında pozitif ve anlamlı bir ilişki bulunmuştur $\left(r_{\mathrm{pb}}=0,386, n=199, p<0,001\right)$. Bu sonuçlar doğrultusunda reklam içeriği ile davranışa yönelik tutum arasındaki ilişki içerisinde çevresel endişenin düzenleyici rolünü (Hipotez 1) değerlendirmek için PROCESS 3.0 makrosu aracılığı ile en küçük kareler yöntemiyle regresyon temelli basit düzenleyici analizi gerçekleştirilmiştir. Bu modelde, bir önceki çalışmada olduğu gibi reklam içerikleri ile davranışa yönelik tutum arasındaki ilişkide çevresel endişe düzeyinin düzenleyici rolü test edilmiştir (Hipotez 1). Modelin geneli anlamlıdır, $R^{2}=0,233, F(3,195)=23,59, p<0,001$.

Modeldeki bağımsız değişkenler arasında çoklu doğrusal bağlantı sorunu, reklam içeriği için VIF=1,00, çevresel endişe için 2,11 ve etkileşim değişkeni olan reklam içeriği $x$ çevresel endişe için $\mathrm{VIF}=2,10$ olmasından dolayı bulunmamaktadır (Hair vd., 2010: 201). Analizde olası değişen varyans sorununu önlemek için HC3 standart hata tahmincisi kullanılmıştır (Long ve Ervin, 2000). Modele etkileşim değişkeni olan (reklam içerikleri) $x$ (çevresel endişenin) dahil edilmesi modelin davranışa yönelik tutum değişkenindeki varyansı açıklama gücünde anlamlı bir artışa neden olmuştur. $\Delta R^{2}=0,02, F(1,195)=4,63, p<0,03$. Çevresel endişe düzenleyici değişkeninin değeri 4,58 ve üzeri puan olduğu durumda reklam içeriği davranışa yönelik tutumu 
pozitif ve anlamlı bir şekilde etkilemeye başlamaktadır $(\beta=0,39, p=0,03, \mathrm{Cl}=0,03 \rightarrow 0,75)$. Bu değerin altında reklam içeriğinin davranışa yönelik tutuma etkisi sıfırdan farklı değildir (Şekil 8).

Reklam içeriği ile satın alma niyeti arasındaki ilişkide davranışa yönelik tutumun aracı rolü otomobil deneyinde destek bulmuştu (Hipotez 2). Bu hipotezin tutarlı̆ını belirlemek amacıyla farklı bir ürün olan pet şişeli su örneği için toplanan verilerle bir önceki deneyde uygulanan test tekrar edilmiştir. PROCES 3.0 makrosu aracılığıyla en küçük kareler yöntemiyle uygulanan regresyon analizinin sonuçları Tablo 5 'te sunulmuştur. Reklam içeriğinin davranışa yönelik tutum aracılığıyla satın alma niyetine dolaylı etkisi istatistiki olarak anlamlıdır $(a b=0,956, \mathrm{Cl}=0,633 \rightarrow 1,294)$. Dolaylı etkinin güven aralığı 10.000 bootstrap ve düzeltilmiş hata tekniği kullanılarak elde edilen örneklemlerden elde edilmiştir. Dolaylı etkiyi gösteren katsayı güven aralığının sıfır içermemesi nedeniyle anlamlıdır (Preacher vd., 2007).

Şekil 8. Pet Şişeli Su Reklam İçeriğinin, Çevresel Endişe Değerlerinde Koşullu Etkisi İçin Johnson-Neyman Anlamlılık Bölgeleri

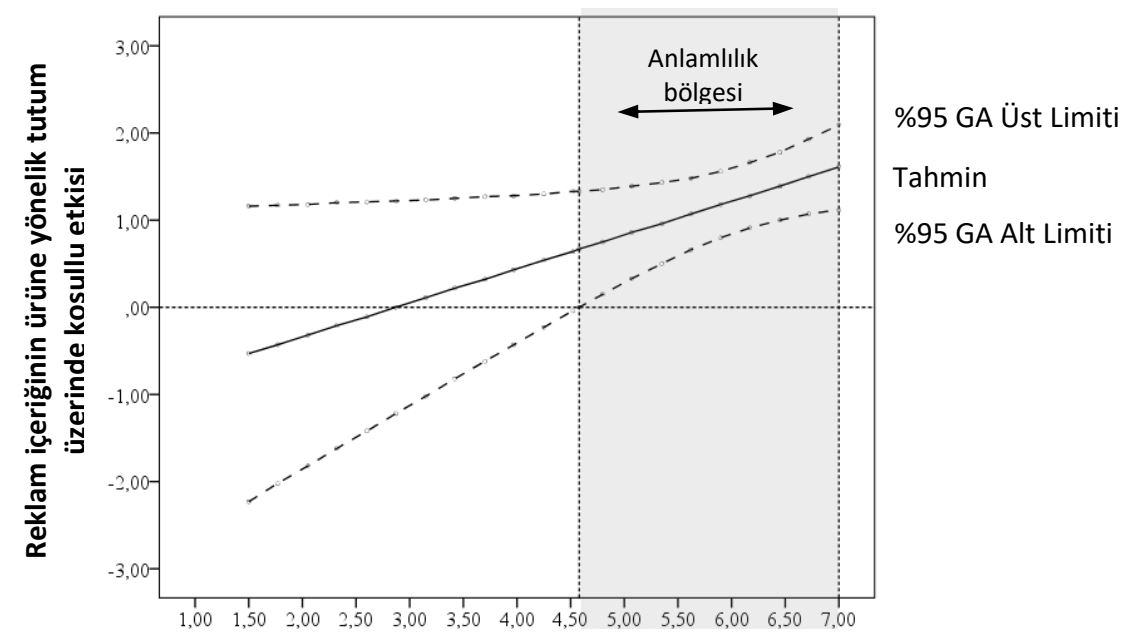

Çevresel Endişe

Yeşil içerikli reklama maruz kalan katılımcıların davranışa yönelik tutumları aracılığıyla oluşan satın alma niyetleri diğer gruba göre 0,956 birim daha yüksektir. Diğer yandan reklam içeriğinin, satın alma niyetine doğrudan etkisi incelendiğinde istatistiki olarak anlamlı bir sonuç göstermediği anlaşılmıştır $\left(c^{\prime}=0,121\right.$, $p=0,275, \mathrm{Cl}=-0,097 \rightarrow 0,340)$. Bir başka ifadeyle katılımcıların maruz kaldıkları reklam içeriğine göre davranışa yönelik tutumları eşitken satın alma niyetlerine anlamlı bir etki olmamaktadır. Reklam içeriğinin satın alma niyetine toplam etkisi istatistiki olarak anlamlı çıkmıştır ( $6=1,077, p<0,001, \mathrm{Cl}=0,708 \rightarrow 1,447)$. Bu deneyde de toplam etkinin anlamlı olması ve doğrudan etkinin anlamsız çıkması reklam içeriği ve satın alma niyeti arasında davranışa yönelik tutumun tam aracı rolünü göstermektedir (Baron ve Kenny, 1986).

Tablo 5. Pet Şişeli Su Reklamı Için Basit Aracı Modelinin Analiz Sonuçları

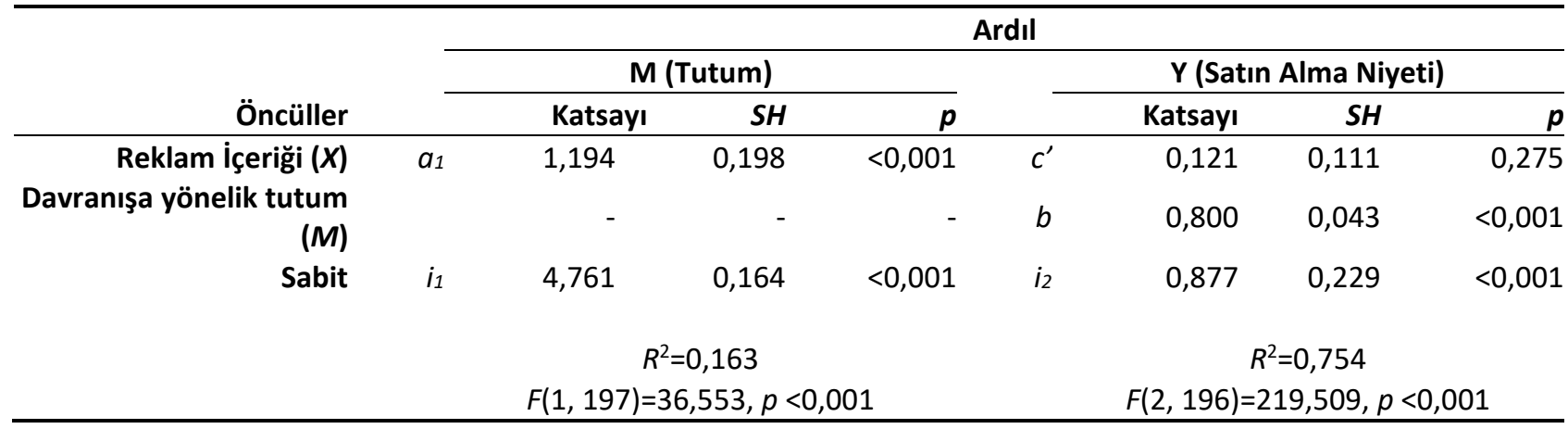


Pet şişeli su ürünü deneyinde bir önceki deney sonuçları ile tutarlılığı sorgulanan son hipotez, reklam içeriğinin satın alma niyeti üzerine etkisinin bir kısmının dolaylı olarak davranışa yönelik tutum aracılığıyla taşındığını ve bu sürecin çevresel endişe tarafından düzenlendiğini öne sürmekteydi (Hipotez 3). Tablo 6’da bu hipotezin testine yönelik gerçekleştirilen regresyon sonuçlarının özeti sunulmuştur. Reklam içeriği ve çevresel endişe düzeyi sabit tutulduğunda davranışa yönelik tutumlarını daha yüksek olarak puanlayan katılımcılar aynı zamanda satın alma niyetlerine de yüksek puanlamışlardır $(b=0,800, p<0,001)$.

Tablo 6. Kavramsal Modelin Analiz Sonuçları

\begin{tabular}{|c|c|c|c|c|c|c|c|c|}
\hline \multirow[b]{3}{*}{ Öncüller } & \multicolumn{8}{|c|}{ Ardıl } \\
\hline & \multicolumn{4}{|c|}{$\mathrm{M}$ (Tutum) } & \multicolumn{4}{|c|}{ Y (Satın Alma Niyeti) } \\
\hline & & Katsayı & $S H$ & $p$ & & Katsayı & $S H$ & $\underline{p}$ \\
\hline Reklam İçeriği $(X)$ & $a_{1}$ & $-1,117$ & 1,125 & 0,322 & $c^{\prime}$ & 0,121 & 0,111 & 0,275 \\
\hline $\begin{array}{r}\text { Davranışa yönelik Tutum } \\
\text { (M) }\end{array}$ & & & & & $b$ & 0,800 & 0,043 & $<0,001$ \\
\hline Çevresel Endişe $(W)$ & $a_{2}$ & 0,076 & 0,128 & 0,237 & & - & - & \\
\hline$(W) \times(x)$ & $a_{3}$ & 0,389 & 0,181 & 0,033 & & - & - & \\
\hline Sabit & $i_{1}$ & 4,300 & 0,774 & $<0,001$ & $i_{2}$ & 0,877 & 0,229 & $<0,001$ \\
\hline & & $R^{2}=0,233$ & & & & $R^{2}=0,7$ & & \\
\hline & & $95)=23,58$ & $<0,001$ & & & 6) $=219$, & $p<0,00$ & \\
\hline
\end{tabular}

Bu sonuç bir önceki otomobil deneyinin test sonuçları ile tutarlıdır. Reklam içeriğinin davranışa yönelik tutuma olan koşullu etkisi ile davranışa yönelik tutumun satın alma niyetine olan etkisini birleştirdiğimizde reklam içeriğinin davranışa yönelik tutum aracılı̆ıyla satın alma niyeti üzerine koşullu etkisi ile sonuçlanmaktadır.

\section{Sonuç}

Bu araştırma kapsamında gerçekleştirilen deneysel çalışmalar, öne sürülen kavramsal modele yönelik somut sonuçlar vermiştir. Geçmiş çalışmalara dayanılarak oluşturulan araştırmanın kavramsal modeli reklam içeriklerinin tüketicilerin davranışa yönelik tutumları aracılı̆ı̆yla satın alma niyetlerini etkilerken, bu etkinin onların çevresel endişe düzeyine bağımlı olacağını varsaymaktadır. Araştırmada, davranışsal kararlar konusunda yaygın olarak kullanılan teorilerden biri olan planlı davranış teorisi, tutumlarla davranışlar arasındaki bağlantıyı açıklayan ve sebep-sonuç ilişkisine dayanan süreçleri temsil eden kabul görmüş bir teori olması nedeniyle tercih edilmiştir. Teoriye göre davranış, eylemin olası sonuçları hakkındaki inançlar, algılanan sosyal baskı veya öznel normlar ve eylem üzerindeki algılanan davranışsal kontrol tarafından belirlenmektedir. Bu faktörler ne kadar kuvvetli ise, kişinin davranış niyetinin oluşması ve sonuç olarak davranış eyleminin gerçekleşmesi ihtimali de o derece yüksek olacaktır (Ajzen, 1985). Planlı davranış teorisi, davranışı ve davranışsal niyeti belirleyen faktörleri kavramsallaştırmak, ölçmek ve ampirik olarak tanımlamak için iyi bir çerçeve olarak görülmektedir (Vermeir ve Verbeke, 2008).

Niyetin dolayısıyla davranışın en temel belirleyicisi olan davranışa yönelik tutum, planlı davranış teorisinin diğer boyutları olan öznel norm ve algılanan davranışsal kontrol değişkenlerine göre niyeti daha fazla etkilemektedir (Ajzen, 2008). Krueger vd. (2000) niyetlerin başarılı bir şekilde davranışları tahmin ettiğini, tutumların da başarılı bir şekilde niyetleri tahmin ettiğini ifade etmişlerdir. Tutumlar ne kadar pozitif olursa davranışa yönelik niyetler de o ölçüde yüksek olacaktır. Diğer konularda olduğu gibi yeşil satın alma niyetinin en temel etkileyicisinin de davranışa yönelik tutum değişkeni olduğuna yönelik bulgular bulunmaktadır (Minton ve Rose, 1997). Tüm bu araştırmalardan hareketle bu araştırmada, tüketicilerin maruz kaldıkları reklamlara yönelik tepkileri, tutumları bağlamında incelenmiştir. Bu bağlamda kurgulanarak uygulaması gerçekleştirilen her iki deneyin sonuçları da araştırma hipotezlerine destek vermiştir. 
Araştırma kapsamında ilk olarak reklam içeriklerinin tüketicilerin davranışa yönelik tutumlarını etkileyeceği ve bu etkinin de onların çevresel endişe düzeyine bağımlı olacağı varsayılmıştır (Hipotez 1). Bu hipotez aynı zamanda öne sürülen kavramsal modelin ilk alt modelidir. Model bu çalışma kapsamında daha önce gerçekleştirilmiş olan ön çalışmalarla belirlenen ürün gruplarının her ikisi için de destek bulmuştur. Reklam içeriklerinin davranışa yönelik tutuma olan etkisi bireyin çevresel endişe düzeyine bağımlıdır. Bir başka ifadeyle yeşil reklam içerikleri tüketicilerin davranışa yönelik tutumunu eğer bireyin çevresel endişe düzeyi belirli bir sevideyse etkilemeye başlamaktadır. Dolayısıyla yeşil içerikli reklamların tüketicilerde satın almaya yönelik tutumu ancak tüketicilerin belirli bir çevresel endişe düzeyine sahip olması durumunda pozitif olarak etkilediği söylenebilir. Ayrıca deneylerde kullanılan ürünler göz önüne alındığında bu etki mekanizmasının özellikli ürünlerde (örneğin; otomobil) daha yüksek bir çevresel endişe düzeyinde gerçekleştiği ancak kolayda ürünlerde (örneğin; pet şişeli su) ise daha düşük bir çevresel endişe düzeyinde oluşmaya başladığı gözlenmiştir. Bu bağlamda reklam içeriği ile davranışa yönelik tutum arasındaki ilişkinin çevresel endişe düzeyine bağımlıı̆̆ı ürün kategorilerine göre değişkenlik gösterdiği söylenebilir.

Araştırmada kavramsal modelin ikinci alt modeli olan reklam içerikleri ile satın alma niyeti arasında davranışa yönelik tutumun aracı rolü de sorgulanmıştır (Hipotez 2). Bu bağlamda her iki deneyde de davranışa yönelik tutumun reklam içerikleri ile satın alma niyeti arasında tam aracılık rolü olduğuna yönelik destek bulunmuştur. Bir başka ifadeyle reklam içeriklerinin, satın alma niyetine doğrudan etkisi bulunmazken dolaylı olarak davranışa yönelik tutum aracılığıyla bu etkinin gerçekleştiği analizler sonucunda belirlenmiştir. Bu sonuç reklam içerikleri ile satın alma davranışı arasındaki ilişkinin nasıl gerçekleştiğini anlamamızda fayda sağlayan bir başka bulgu olmasının yanında planlı davranış teorisinin varsayımını da destekleyen bir bulgudur.

Araştırmada son olarak kavramsal model bütünüyle test edilmiştir. Test sonucunda reklam içeriklerinin davranışa yönelik tutum aracılığıyla satın ama niyetine dolaylı etkisinin çevresel endişe düzeyine bağımlı olduğu belirlenmiştir. Bu dolaylı etki tüketicilerin çevresel endişe düzeylerine göre şekillenmektedir. Endişe düzeyi belirli bir noktanın üzerinde olduğu durumlarda dolaylı etki anlamlı olmakta, belirli bir seviyenin altındaysa istatistiki olarak anlamlı olmamaktadır. Dolayısıyla yeşil içerikli reklamların tüketicilerin satın alma niyetlerini ürüne yönelik tutumları aracılığıyla pozitif yönde etkilemesi ancak tüketicilerin belirli bir çevresel endişeye sahip olduklarında gerçekleşmektedir.

Araştırmanın uygulamacılar açısından da sonuçları bulunmaktadır. Tüketicilerde artan çevre duyarlılığı nedeniyle, işletmeler de ürünlerinin/hizmetlerinin yeşil ve sürdürülebilir özelliklere sahip olduğunu ifade etmeye başlamışlardır. Yeşil tüketim kalıplarını ve yeşil tüketicileri anlayabilmek pazarlama yöneticileri için kritik bir hâl almıştır. Bunun doğal sonucu olarak da reklam sektöründe yeşil iddialara sahip reklamlarda büyük oranda bir artış görülmektedir. Bu bağlamda yeşil tüketim konusunda işletmelerin tanıtım çabalarında basılı, yazılı ya da çevrimiçi reklam kararlarını verirken tüketicilerde satın alma niyetinin nasıl gerçekleştiğini ve bu sürecin ne zaman farklılaştığını bilmelerinde fayda olduğu düşünülmektedir. Özellikle firmalar açısından hedefledikleri pazarlarda tüketicilerin çevresel endişe düzeylerinin bilinmesi onların satın alma niyeti oluşumunda reklam içeriğinin ne kadar etkisi olacağını belirleyecektir. Ayrıca çevresel endişe düzeyinin ürün kategorisine göre değişkenlik gösterdiği de göz önünde tutulmalıdır. Özellikli ürünlerde çevresel endişe düzeyi daha yüksek olduğunda bu mekanizma etkisini göstermektedir.

Araştırmanın sınırlıııları içerisinde bu tüketim eğilimleri, katılımcıların demografik ve psikografik değerleri temelinde tutum kavramı merkeze alınarak gerçekleştirilmiştir. Araştırmanın sonuçları bu değişkenlerle araştırmanın yapıldığı toplum ve örneklemle, reklamı yapılan ürün kategorileriyle sınırlıdır. Ancak yeşil tüketim kararları içinde yaşanılan toplum, ait olunan sosyal sınıf, kültür, yaşam tarzları, hükümet politikaları, çevreci örgütlerin eylemleri, bireylerin ve toplumların materyalizm, refah ve gelişmişlik düzeyleri gibi pek çok makro değişkenden de etkilenebilmektedir. Pazarlama uygulamacıları ve karar vericileri, makro ve mikro düzeyde oluşan tüm bu değişkenleri göz önünde bulundurmalarında fayda olacağı düşünülmektedir. 


\section{Son Notlar}

* Bu çalışma, Bilge Nur Öztürk'ün Doç. Dr. Serkan Akıncı'nın danışmanlığında hazırlanan ve 2016 yılında tamamlanan "Reklam içeriğinin satın alma niyetine etkisi: Tutumun ve çevresel endişenin rolü" başlıklı tezinden üretilmiştir.

\section{Teşekkür}

* Makalenin son okumasını yaparak önerilerde bulunan değerli meslektaşımız Doç. Dr. Gökhan AKYüZ'e ve değerli yorumları ile makalenin geliştirilmesindeki katkılarından dolayı anonim hakemlere teşekkür ederiz.

\section{Kaynaklar}

Ajzen, I. (1985). From intentions to actions: A theory of planned behavior. In J. Kuhl \& J. Beckmann (Eds.), Action Control (pp. 11-39). Berlin: Springer.

Ajzen, I. (1991). The theory of planned behavior. Organizational Behavior and Human Decision Process, 50(2), $179-211$.

Ajzen, I. (2002). Constructing a TpB questionnaire: Conceptual and methodological considerations. Retrieved from http://citeseerx.ist.psu.edu/viewdoc/download?doi=10.1.1.601.956\&rep=rep1\&type=pdf

Ajzen, I. (2005). Attitudes, personality and behavior (2nd ed.). McGraw Hill.

Ajzen, I. (2008). Consumer attitudes and behavior. In C. P. Haugtvedt, P. M. Herr, \& F. R. Cardes (Eds.), Handbook of Consumer Psychology (pp. 525-548). New York: Lawrence Erlbaum Associates.

Ajzen, I., \& Fishbein, M. (1977). Attitude-behavior relations: A theoretical analysis and review of empirical research. Psychological Bulletin, 84(5), 888-918. https://doi.org/10.1037/0033-2909.84.5.888

Ajzen, I., \& Madden, T. J. (1986). Prediction of goal-directed behavior: Attitudes, intentions, and perceived behavioral control. Journal of Experimental Social Psychology, 22(5), 453-474. https://doi.org/10.1016/00221031(86)90045-4

Akehurst, G., Afonso, C., \& Gonçalves, H. M. (2012). Re-examining green purchase behaviour and the green consumer profile: New evidences. Management Decision, 50(5), 972-988. https://doi.org/10.1108/00251741211227726

Alniacik, U., \& Yilmaz, C. (2012). The Effectiveness of green advertising: Influences of claim specificity, product's environmental relevance and consumers' pro-environmental orientation. Amfiteatru Economic Journal, 14(31), 207-222.

Bamberg, S. (2003). How does environmental concern influence specific environmentally related behaviors? A new answer to an old question, 23, 21-32. https://doi.org/10.1016/S0272-4944(02)00078-6

Baron, R. M., \& Kenny, D. A. (1986). The moderator-mediator variable distinction in social psychological research: Conceptual, strategic, and statistical considerations. Journal of Personality and Social Psychology, 51(6), 11731182. https://doi.org/10.1037/0022-3514.51.6.1173

Bhatnagar, N., \& McKay-Nesbitt, J. (2016). Pro-environment advertising messages: The role of regulatory focus. International Journal of Advertising, 35(1), 4-22. https://doi.org/10.1080/02650487.2015.1101225

Brooker, G. (1976). The self-actualizing socially conscious consumer. Journal of Consumer Research, 3(2), 107. https://doi.org/10.1086/208658

Diamantopoulos, A., Schlegelmilch, B. B., Sinkovics, R. R., \& Bohlen, G. M. (2003). Can socio-demographics still play a role in profiling green consumers? A review of the evidence and an empirical investigation. Journal of Business Research, 56(6), 465-480. https://doi.org/10.1016/S0148-2963(01)00241-7

Dunlap, R. E., \& Van Liere, K. D. (1978). The new environmental paradigm. Journal of Environmental Education, 9(4), 1019. https://doi.org/10.3200/JOEE.40.1.19-28

Dunlap, R. E., Van Liere, K. D., Mertig, A. G., \& Jones, R. E. (2000). Measuring endorsement of the new ecological paradigm: A Revised NEP scale. Journal of Social Issues, 56(3), 425-442. https://doi.org/10.1111/00224537.00176

Fishbein, M., \& Ajzen, I. (2011). Predicting and changing behavior: The reasoned action approach. New York: Psychology Press. Retrieved from http://www.tandfebooks.com/isbn/9780203838020 
Granzin, K. L., \& Olsen, J. E. (1991). Characterizing participants in activities protecting the environment: A focus on donating, recycling, and conservation behaviors. Journal of Public Policy \& Marketing, 10(2), 1-27. https://doi.org/10.2307/30000233

Hair, J. F. J., Black, W. C., Babin, B. J., \& Anderson, R. E. (2010). Multivariate Data analysis a global perspective (7th ed.). New Jersey: Pearson Prentice Hall.

Hayes, A. F. (2013). Introduction to mediation, moderation, and conditional process analysis: A regression-based approach. The Guilford Press.

Hayes, A. F. (2018). Introduction to mediation, moderation, and conditional process analysis: A regression-based approach (2nd ed.). New York: The Guilford Press.

Hult, G. T. M. (2011). Market-focused sustainability: Market orientation plus! Journal of the Academy of Marketing Science, 39(1), 1-6. https://doi.org/10.1007/s11747-010-0223-4

Jackson, J. E. (1983). Measuring the demand for environmental quality with survey data. The Journal of Politics, 45(2), 335-350.

Kinnear, T. C., Taylor, J. R., \& Ahmed, S. A. (1974). Ecologically concerned consumers: Who are they? Journal of Marketing, 38(2), 20. https://doi.org/10.2307/1250192

Kotler, P. (2011). Reinventing marketing to manage the environmental ımperative. Journal of Marketing, 75(4), 132135. https://doi.org/10.1509/jmkg.75.4.132

Krueger, N. F., Reilly, M. D., \& Carsrud, A. L. (2000). Competing models of entrepreneurial intentions. Journal of Business Venturing, 15(5), 411-432. https://doi.org/10.1016/S0883-9026(98)00033-0

Lin, P. C., \& Huang, Y. H. (2012). The influence factors on choice behavior regarding green products based on the theory of consumption values. Journal of Cleaner Production, 22(1), 11-18. https://doi.org/10.1016/j.jclepro.2011.10.002

Long, J. S., \& Ervin, L. H. (2000). Using Heteroscedasticity consistent standard errors in the linera regression model. The American Statistician, 54(3), 217-224. https://doi.org/10.2307/2685594

MacKinnon, D. P. (2008). Introduction to statistical mediation analysis. Lawrence Erlbaum Associates.

Matthes, J., Wonneberger, A., \& Schmuck, D. (2014). Consumers' green involvement and the persuasive effects of emotional versus functional ads. Journal of Business Research, 67(9), 1885-1893. https://doi.org/10.1016/j.jbusres.2013.11.054

Minton, A. P., \& Rose, R. L. (1997). The effects of environmental concern on environmentally friendly consumer behavior: An exploratory study. Journal of Business Research, 40(1), 37-48. https://doi.org/10.1016/S01482963(96)00209-3

Minton, E. A., Kahle, L. R., \& Kim, C. H. (2015). Religion and motives for sustainable behaviors: A cross-cultural comparison and contrast. Journal of Business Research, 68(9), $1937-1944$. https://doi.org/10.1016/j.jbusres.2015.01.003

Mohai, P. (1985). Public concern and elite Involvement in environmental- Conservation issues. Social Science Quarterly, 66(4), 820-838.

Muller, D., Judd, C. M., \& Yzerbyt, V. Y. (2005). When moderation is mediated and mediation is moderated. Journal of Personality and Social Psychology, 89(6), 852-863. https://doi.org/10.1037/0022-3514.89.6.852

Netemeyer, R. G., Bearden, W. O., \& Sharma, S. (2003). Scaling procedures: Issues and applications. Sage.

Paul, J., Modi, A., \& Patel, J. (2016). Predicting green product consumption using theory of planned behavior and reasoned action. Journal of Retailing and Consumer Services, 29, $123-134$. https://doi.org/10.1016/j.jretconser.2015.11.006

Peattie, K. (2010). Green consumption: Behavior and norms. Annual Review of Environment and Resources, 35(1), 195228. https://doi.org/10.1146/annurev-environ-032609-094328

Peattie, K., \& Peattie, S. (2009). Social marketing: A pathway to consumption reduction? Journal of Business Research, 62(2), 260-268. https://doi.org/10.1016/j.jbusres.2008.01.033

Pollack, J. M., Vanepps, E. M., \& Hayes, A. F. (2012). The moderating role of social ties on entrepreneurs' depressed affect and withdrawal intentions in response to economic stress. Journal of Internet Banking and Commerce, 33(6), 789-910. https://doi.org/10.1002/job.1794 The 
Reklam İçeriğinin Satın Alma Niyetine Etkisi: Davranışa Yönelik Tutumun Aracı ve Çevresel Endişenin Düzenleyici Rolü

Preacher, K. J., Rucker, D. D., \& Hayes, A. F. (2007). Addressing moderated mediation hypotheses: Theory, methods, and prescriptions. Multivariate Behavioral Research, 42(1), 185-227. Retrieved from http://www.tandfonline.com/doi/abs/10.1080/00273170701341316

Roberts, D. A., \& Bacon, D. R. (1997). Exploring the subtle relationship between environmental concern and ecological conscious consumer behavior. Journal of Business Research, 40(96), 79-89.

Roberts, J. A. (1996). Green consumers in the 1990s: Profile and implications for advertising. Journal of Business Research, 36(3), 217-231.

Schwepker, Charles H., J., \& Cornwell, T. B. (1991). An Examination of Ecologically concerned consumers and their intention to purchase ecologically packaged products. Journal of Public Policy \& Marketing, 10(2), 77-101. https://doi.org/10.1161/ATVBAHA.108.183210

Sharma, S., Durand, R. M., \& Gur-Arie, O. (1981). Identification and analysis of moderator variables. Journal of Marketing Research, 18(3), 291. https://doi.org/10.2307/3150970

Sheppard, B. H., Hartwick, J., \& Warshaw, P. R. (1988). The theory of reasoned action: A meta-analysis of past research with recommendations for modifications and future research. Journal of Consumer Research, 15(3), 325. https://doi.org/10.1086/209170

Shrum, L. J., McCarty, J. A., \& Lowrey, T. M. (1995). Buyer characteristics of the green consumer and their implications for advertising strategy. Journal of Advertising, 24(2), 71-82. https://doi.org/10.1080/00913367.1995.10673477

Straughan, R. D., \& Roberts, J. a. (1999). Environmental segmentation alternatives: A look at green consumer behavior in the new millennium. Journal of Consumer Marketing, 16(6), 558-575. https://doi.org/10.1108/07363769910297506

Tonglet, M. (2002). Consumer misbehavior: An exploratory study of shoplifting. Journal of Consumer Behaviour, 1(4), 336-354. https://doi.org/10.1002/cb.79

Van Liere, K. D., \& Dunlap, R. E. (1980). The social bases of environmental concern: A review of hypotheses, explanations and empirical evidence. The Public Opinion Quarterly, 44(2), 181-197.

Vermeir, I., \& Verbeke, W. (2008). Sustainable food consumption among young adults in Belgium: Theory of planned behaviour and the role of confidence and values. Ecological Economics, 64(3), 542-553. https://doi.org/10.1016/j.ecolecon.2007.03.007

Vining, J., \& Ebreo, A. (1990). What makes a recycler? A comparison of recyclers and nonrecyclers. Environment and Behavior, 22(1), 55-73.

Zhao, H. H., Gao, Q., Wu, Y. P., Wang, Y., \& Zhu, X. D. (2014). What affects green consumer behavior in China? A case study from Qingdao. Journal of Cleaner Production, 63, 143-151. https://doi.org/10.1016/j.jclepro.2013.05.021 